\title{
Characterization of individual ice residual particles by the single droplet freezing method: a case study in the Asian dust outflow region
}

\author{
Ayumi Iwata ${ }^{1}$ and Atsushi Matsuki ${ }^{2}$ \\ ${ }^{1}$ Graduate School of Natural Science and Technology, Kanazawa University, Kakuma, Kanazawa, Ishikawa, 920-1192, Japan \\ ${ }^{2}$ Institute of Nature and Environmental Technology, Kanazawa University, Kakuma, Kanazawa, Ishikawa, 920-1192, Japan
}

Correspondence: Ayumi Iwata (iayumi@stu.kanazawa-u.ac.jp) and Atsushi Matsuki (matsuki@staff.kanazawa-u.ac.jp)

Received: 31 March 2017 - Discussion started: 24 July 2017

Revised: 20 November 2017 - Accepted: 6 December 2017 - Published: 7 February 2018

\begin{abstract}
In order to better characterize ice nucleating (IN) aerosol particles in the atmosphere, we investigated the chemical composition, mixing state, and morphology of atmospheric aerosols that nucleate ice under conditions relevant for mixed-phase clouds. Five standard mineral dust samples (quartz, K-feldspar, Na-feldspar, Arizona test dust, and Asian dust source particles) were compared with actual aerosol particles collected from the west coast of Japan (the city of Kanazawa) during Asian dust events in February and April 2016. Following droplet activation by particles deposited on a hydrophobic Si (silicon) wafer substrate under supersaturated air, individual IN particles were located using an optical microscope by gradually cooling the temperature to $-30^{\circ} \mathrm{C}$. For the aerosol samples, both the IN active particles and non-active particles were analyzed individually by atomic force microscopy (AFM), micro-Raman spectroscopy, and scanning electron microscopy (SEM) coupled with energy dispersive X-ray spectroscopy (EDX). Heterogeneous ice nucleation in all standard mineral dust samples tested in this study was observed at consistently higher temperatures (e.g., -22.2 to $-24.2^{\circ} \mathrm{C}$ with $\mathrm{K}$-feldspar) than the homogeneous freezing temperature $\left(-36.5^{\circ} \mathrm{C}\right)$. Meanwhile, most of the IN active atmospheric particles formed ice below $-28^{\circ} \mathrm{C}$, i.e., at lower temperatures than the standard mineral dust samples of pure components. The most abundant IN active particles above $-30^{\circ} \mathrm{C}$ were predominantly irregular solid particles that showed clay mineral characteristics (or mixtures of several mineral components). Other than clay, Ca-rich particles internally mixed with other components, such as sulfate, were also regarded as IN active particle types. Moreover, sea salt particles were predominantly
\end{abstract}

found in the non-active fraction, and internal mixing with sea salt clearly acted as a significant inhibiting agent for the ice nucleation activity of mineral dust particles. Also, relatively pure or fresh calcite, $\mathrm{Ca}\left(\mathrm{NO}_{3}\right)_{2}$, and $\left(\mathrm{NH}_{4}\right)_{2} \mathrm{SO}_{4}$ particles were more often found in the non-active fraction. In this study, we demonstrated the capability of the combined single droplet freezing method and thorough individual particle analysis to characterize the ice nucleation activity of atmospheric aerosols. We also found that dramatic changes in the particle mixing states during long-range transport had a complex effect on the ice nucleation activity of the host aerosol particles. A case study in the Asian dust outflow region highlighted the need to consider particle mixing states, which can dramatically influence ice nucleation activity.

\section{Introduction}

Ice nucleation in clouds substantially affects the climate by significantly impacting the radiation balance and precipitation processes in the Earth's atmosphere (Lohmann and Feichter, 2005; Rosenfeld et al., 2008; Flato et al., 2013). Most of the initial precipitation process in midlatitude regions involves ice nucleation in mixed-phase clouds, where supercooled water droplets and ice crystals coexist (Pruppacher and Klett, 1997; Murray et al., 2012). Therefore, an understanding of ice nucleation is crucial to predicting precipitation and cloud radiative properties.

Pure water droplets generally maintain their liquid state, even in temperatures below $0{ }^{\circ} \mathrm{C}$, and remain as supercooled 
water droplets. These pure water droplets spontaneously freeze by cooling to approximately $-37^{\circ} \mathrm{C}$ and below (homogeneous nucleation) (e.g., Koop, 2000; Rosenfeld and Woodley, 2000; Murray et al., 2010, 2012). However, supercooled water droplets in the atmosphere generally form ice crystals at higher temperatures due to the presence of aerosol particles that can nucleate ice (heterogeneous nucleation). Traditionally, heterogeneous nucleation pathways are categorized into four freezing modes: deposition, condensation, immersion, and contact freezing (Pruppacher and Klett, 1997; Cantrell and Heymsfield, 2005). The physical and chemical properties of aerosols, which act as ice nuclei, play an essential role in the formation of ice crystals. However, the response of ice nucleation processes to changes in host aerosol properties is still poorly understood due to a lack of understanding of the basic aerosol particle interactions leading to ice crystal formation. Therefore, considerable uncertainty still exists regarding the prediction of ice nucleation that would lead to climate changes in the atmosphere.

Many previous ice nucleation experiments have been performed under laboratory conditions, providing valuable information on the ice nucleation properties of pure component particles and artificially generated aerosol mixtures (Pruppacher and Klett, 1997; Hoose and Möhler, 2012; Murray et al., 2012). Based on these results, while mineral dust and biological particles are generally regarded as efficient ice nuclei (Morris et al., 2004; Connolly et al., 2009; Niemand et al., 2012), ice nucleation within mixed-phase clouds involving soot and organic particles is still not as clearly demonstrated due to the diverse chemical composition and different experimental conditions (DeMott, 1990; Kireeva et al., 2009). On the other hand, sea salt and sulfates are often not considered as efficient ice nuclei under mixed-phase conditions. However, the situation is even more complex in the ambient atmosphere, where particles are often present as complex mixtures of different compounds and minerals. Although recent laboratory experiments have considered the influence of aerosol mixing states (Sullivan et al., 2010; Kulkarni et al., 2014; Augustin-Bauditz et al., 2016), the complexity of the atmosphere has not yet been fully represented.

Over the last decade, several techniques have emerged, such as the counter vertical impactor (CVI), which is capable of distinguishing ice residue particles from background atmospheric particles (non-active particles) (Klein et al., 2010; Cziczo et al., 2013). Using these techniques, several field studies have been conducted to directly extract ice crystal residues from cirrus clouds (i.e., pure ice phase). This enabled direct and detailed investigation on the particles representative of the actual deposition-mode ice nuclei in cirrus clouds.

The investigation of ice nuclei in mixed-phase clouds (i.e., dominated by immersion and condensation freezing modes), however, requires a different and much more demanding approach to ensure the complete isolation of ice crystals from numerous supercooled droplets and other interstitial aerosol particles. The accuracy required to ensure complete separation of ice nuclei is very challenging because the number of ice nuclei is believed to be on the order of only 1 out of $10^{5}-10^{6}$ ambient particles and supercooled droplets in the free troposphere (e.g., Rogers et al., 1998; Prenni et al., 2012; Ardon-Dryer and Levin, 2014). It is also generally accepted that one single ice crystal grows at the expense of $10^{5}-10^{6}$ evaporating droplets inside mixed-phase clouds (the Bergeron-Findeisen or so-called "cold rain" process) (Korolev, 2007).

In order to overcome the issue of ice nuclei extraction from mixed-phase clouds, several techniques such as the Ice-CVI or the Ice Selective Inlet (ISI) have been proposed (Mertes et al., 2007; Kupizewski et al., 2014), and efforts have been made to characterize ice nuclei using these instruments (Kamphus et al., 2010; Ebert et al., 2011). Worringen et al. (2015) reported the size distribution and chemical components of ice residues from mixed-phase clouds collected by three different techniques (Ice-CVI, ISI, and ice nuclei counter combined with CVI) and found that silicates, Carich, carbonaceous, and metal oxide particles constitute the major groups of ice nuclei. However, they also reported discrepancies between the results obtained from the three different sampling techniques and attributed them to potential bias arising from the artifacts such as the possible generation of particles within the instruments and the inherently scarce number of ice nuclei in the atmosphere. Further, it is unknowable whether the ice residues were the actual ice nuclei, because, for example, the riming process can potentially mix cloud condensation nuclei, ice nuclei, and/or interstitial aerosols in the same ice residue.

In addition to these technical difficulties, the number of field studies that have characterized ice residues in mixedphase cloud remains sparse due to the limited access to research locations where such clouds are directly and frequently accessible. Therefore, there is a further need to conduct field measurements in many different locations in order to reflect the regional variations in ice nucleating (IN) particles.

Internal mixing of aerosols commonly takes place during long-range transport in the atmosphere (e.g., Zhang et al., 2003; Sullivan et al., 2007; Iwasaka et al., 2009b). The surface properties of the internally mixed particles following atmospheric processing (reaction, coagulation, and aging) can dramatically change from their original properties (Maring et al., 2003; Trochkine et al., 2003). The internal mixing of particles is an important factor that contributes to the complexity of atmospheric aerosol particles. Although efforts have been made to address the effects of internal mixing on the IN activity of aerosols under conditions relevant for the mixed-phase cloud formation (Sullivan et al., 2010; Kulkarni et al., 2014; Augustin-Bauditz et al., 2016), the complexity of the ambient aerosol has not yet been fully represented by the laboratory-generated aerosols. Therefore, detailed investigation based on the individual particle analysis is necessary 
to relate the internal mixing state of aerosols in the actual atmosphere and their IN activity.

This study is designed to investigate how the morphology, chemical composition, and mixing state of ambient aerosol particles influence their ice nucleation activities under conditions relevant to mixed-phase clouds. Following the ice nucleation experiments, comprehensive analysis of the chemical, physical, and mixing properties of individual aerosol particles collected from the atmosphere was conducted. We further demonstrate the ability to monitor individual IN particles by continuously controlling the ambient conditions during the ice nucleation experiments.

The individual droplet freezing method (IDFM) is the experimental method used in this study, with which ice crystal formation on each particle could be monitored under controlled conditions while keeping individual particles distinct. By drying and evaporating the particles that formed ice crystals and/or droplets, their exact location as ice and/or droplet residues can be observed. Instead of deploying stateof-the-art, in situ ice nuclei samplers into extreme field locations (e.g., low temperature, high altitude, and airborne), this method enables detailed post-sampling analysis on both IN active and non-active particles on an individual particle basis using a fairly simple, conventional sampling method.

Several laboratory studies used a similar cold stage to test the ice nucleation activities of various atmospherically relevant standard particles (Fornea et al., 2009; Baustian et al., 2010; Mason et al., 2015; Whale et al., 2015; Knopf et al., 2014), but not enough studies have been made so far to investigate on the immersion-mode ice nucleation (mixedphase clouds) by the individual particles in the actual atmosphere. We exposed sample particles to the conditions relevant for mixed-phase cloud formation (i.e., immersion and condensation freezing modes), while monitoring the states of individual particles. The sample particles were collected from the west coast of mainland Japan in spring, which is frequently subjected to the influence of continental outflow, which is often associated with plumes of Asian dust mixed with bioaerosols and other anthropogenic pollutants (Matsuki et al., 2005; Maki et al., 2010; Tobo et al., 2010).

\section{Method}

\subsection{Individual droplet freezing method}

The sample particles were deposited onto a Si (silicon) wafer substrate with a hydrophobic coating (Glaco, Soft99 Corporation, Japan). Particles were observed for their position, size, and shape under an optical microscope with $\times 50$ magnification (Olympus, Japan) as shown in Fig. 1b. Subsequently, the substrate was transferred onto a cold stage in a closed cell (THMSG600, Linkam Scientific Instruments, UK). Since the cold stage used in this study is cooled by liquid nitrogen, the tube through which the liquid nitrogen passes in the cold cell becomes a cold trap which can act as an additional sink for the water vapor. Therefore, in this study, all cooling parts except the cold stage surface were covered by insulating material. The temperature measured at the cold stage was calibrated by the substances of known melting points (Akizawa et al., 2016). Furthermore, we confirmed that the temperature gap between the substrate and the cold stage was consistently smaller than $0.3^{\circ} \mathrm{C}$ by observing the melting of pure ice. During the ice nucleation experiment by atmospheric particles, the stage temperature and the dew point were recorded every $1 \mathrm{~s}$. The temperature measurement and the images were synchronized with the PC internal clock.

The dew point of the air introduced into the cell was controlled by mixing dry air (QD10-50, IAC, Japan) and wet air from a water-filled gas scrubbing bottle. Both air flows were kept particle free and their mixing ratio was controlled by a pair of mass flow controllers (MQV9005, Azbil Corporation, Japan). The resulting dew point was also monitored by a chilled mirror-type hygrometer (OptiSonde ${ }^{\mathrm{TM}}$, General Electric Company, Japan). By adjusting both the dew point of the introduced air flow $\left(0.5 \mathrm{~L} \mathrm{~min}^{-1}\right)$ in the range -6 to $-3{ }^{\circ} \mathrm{C}$ and the sample temperature on the cold stage in the range -9 to $-7^{\circ} \mathrm{C}$, the particles on the substrate were exposed to water supersaturation conditions that initiate droplet formation. Thus, increases in particle sizes could be observed (Fig. 1c).

After the air supply was stopped, the temperature of the stage was reduced to $-30^{\circ} \mathrm{C}$ at a rate of $-0.5^{\circ} \mathrm{C} \mathrm{s}^{-1}$. As the temperature of the stage decreased, the saturated water vapor was expected to keep condensing onto the droplets. Thus, the degree of water supersaturation was assumed to be limited to slightly higher than $100 \%$ in terms of relative humidity. The formation of ice crystals on individual droplets can be visually identified by their rapidly growing size with irregular shapes (Fig. 1d).

After relaxing for $10 \mathrm{~s}$ once the substrate reached $-30^{\circ} \mathrm{C}$, the temperature of the stage was increased up to $-10^{\circ} \mathrm{C}$ at $0.5^{\circ} \mathrm{C} \mathrm{s}^{-1}$. After reaching this temperature, dry air flow $\left(0.5 \mathrm{Lmin}^{-1}\right)$ was introduced into the cell to expose the formed ice crystals and droplets to the subsaturation conditions for ice. As a result of evaporation and/or sublimation of water, the nuclei particles were exposed and left visible on the substrate. Finally, the positions of the dried particles were again located under the optical microscope (Fig. 1e). By comparing the optical images before and after the ice nucleation experiments, the individual particles that formed ice crystals (excluding those coalescing with adjacent droplets or crystals) were identified and regarded as IN active particles. Most of the particles collected on the substrates were monitored under an optical microscope with $\times 5$ magnification (Fig. 1a). We did see multiple particles freezing in the same field of view. However, we did not cover all of the collected particles. Therefore, we must note that the non-active particles or IN active particles outside of our field of view are not included in our counts. 


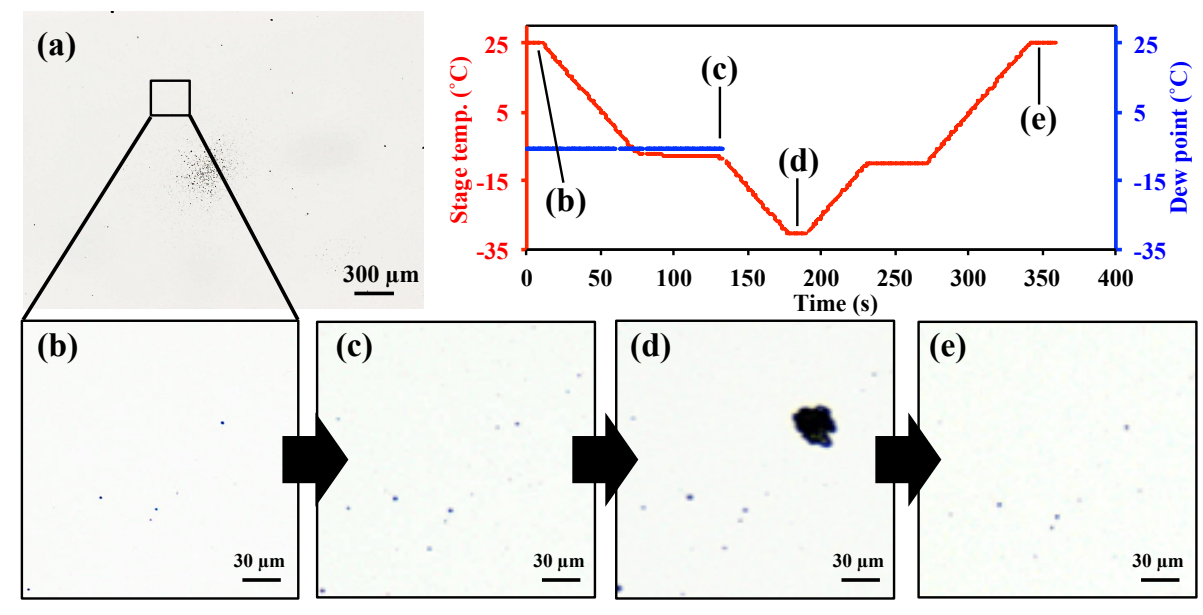

Figure 1. Optical images of sample particles deposited on Si (silicon) wafer substrate before the freezing experiment (a, b), after exposure to water supersaturation conditions at $-9{ }^{\circ} \mathrm{C}(\mathbf{c})$, after cooling to $-30^{\circ} \mathrm{C}(\mathbf{d})$, and after sublimation and evaporation by dry air (e). The inset graph shows the stage temperature and the dew point of the wet air introduced into the cell before exposing the stage to water supersaturation.

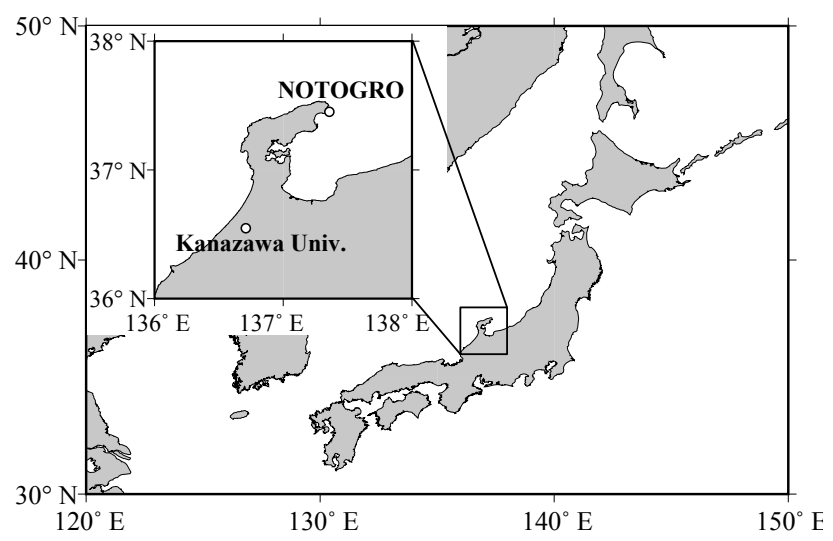

Figure 2. Sampling location of atmospheric particles (Kanazawa University) and location of the observatory for particle concentration monitoring (NOTO Ground-based Research Observatory: NOTOGRO).

\subsection{Preparation of atmospheric aerosol and standard particles}

Using the IDFM, we identified IN particles from the ambient aerosol particles and five types of standard samples. We sampled actual aerosol particles at the Kanazawa University campus $\left(36.54^{\circ} \mathrm{N}, 136.70^{\circ} \mathrm{E}\right.$; 149 ma.s.l.), Japan (Fig. 2), on 28 February 2016 and 10 April 2016. The particles were collected on the substrate (described above) using an impactor with a $50 \%$ cutoff diameter of $1.1 \mu \mathrm{m}$ at a flow rate of $1.0 \mathrm{~L} \mathrm{~min}^{-1}$. The sampling period was set to $60 \mathrm{~s}$ for each substrate. The ambient temperature, pressure, relative humidity, and particle number concentrations were recorded using a mobile meteorological sensor (TR-72Ui, T\&D Corporation, Japan) and an optical particle sizer (OPS 3330, TSI, USA) during the sampling periods.
The ambient atmospheric conditions during the ambient aerosol sampling were $16.7^{\circ} \mathrm{C}, 22.7 \% \mathrm{RH}$, and $1004.25 \mathrm{hPa}$ for the February sample, and $11.7^{\circ} \mathrm{C}, 84.0 \%$, and $994.47 \mathrm{hPa}$ for the April sample. The average concentrations of coarse particles during the two sampling periods $\left(D_{\mathrm{p}}>1.117 \mu \mathrm{m}\right)$ were approximately $1.4 \times 10^{2}$ particles $\mathrm{cm}^{-3}$ for February and $4.1 \times 10^{2}$ particles $\mathrm{cm}^{-3}$ for April, indicating that the concentration for April was 3 times higher than for the February sampling period. No significant difference was observed for the fine particles $\left(D_{\mathrm{p}}<1.117 \mu \mathrm{m}\right)$ between the two periods.

The five standard samples include three types of single mineral component samples (quartz, K-feldspar, Nafeldspar) and two types of soil dust samples (Arizona test dust: ATD, and Asian dust source particles: ADS) that consist of multiple mineral components. The ADS particles were sampled from the surface soil of an arid region near Dunhuang, China $\left(40.21^{\circ} \mathrm{N}, 94.68^{\circ} \mathrm{E}\right)$. K-feldspar and Nafeldspar were purchased from the Bureau of Analyzed Samples, Ltd. K-feldspar has been reported by several studies to show higher ice nucleation activity in mineral dust (Atkinson et al., 2013; Harrison et al., 2016). The quartz sample was purchased from Wako Pure Chemical Industries, Ltd., and it was further crushed with a mortar to decrease the grain size. Both of the soil dust samples (ATD and ADS) were size selected by the impactor and only particles coarser than $1.1 \mu \mathrm{m}$ were used in the ice nucleation experiments.

\subsection{Individual particle analyses}

Both the IN active and non-active particles collected in the atmosphere were analyzed on an individual particle basis using a series of microscopic techniques. Firstly, an atomic force microscopy (AFM) (CombiScope ${ }^{\mathrm{TM}}$ 1000, AIST-NT, Inc., USA) was used to characterize the three-dimensional mor- 
phology, followed by micro-Raman spectroscopy to detect chemical compounds. Furthermore, the exact same particles were analyzed by scanning electron microscopy (SEM) (S3000N, HITACHI, Japan), coupled with energy dispersive X-ray spectroscopy (EDX) (EMAX-500, HORIBA, Japan), in order to obtain their elemental compositions. The reason for conducting AFM observations and micro-Raman analysis prior to SEM-EDX analysis is because the former two methods can be applied under ambient conditions, while the latter requires a high vacuum. The sequence of the multiple analyses was determined by taking into account the potential loss of volatile components within individual particles, especially under conditions of high vacuum and electron beam bombardment. Further, the advantages of AFM over conventional imaging techniques are that it is non-destructive (ambient conditions, no electron beam bombardment, and minimum physical contact) and directly provides the threedimensional structure of individual particles. The technique does not involve any pretreatment (e.g., shadowing particles by spattering a Pt/Pd alloy from a certain angle inside the vacuum) or tilting of samples as is conventionally required, especially when obtaining particle height from the inherently two-dimensional electron micrographs (Adachi et al., 2007; Ueda et al., 2011).

In this study, AFM images were obtained in dynamic mode using a silicon tip (ATEC-NC, NANOSENSORS ${ }^{\mathrm{TM}}$, Switzerland) with a spring constant of $45 \mathrm{Nm}^{-1}$. The resolution of the measurement was set to $20 \mathrm{~nm}$ for each particle. The tip was resonated at approximately $335 \mathrm{kHz}$. In order to avoid sweeping of the particles by physical contact with the tip, the amplitude of the tip was set to $200 \mathrm{~nm}$, and the rate of scanning speed was set to 0.1 lines per second.

The Raman spectra of individual particles were obtained using a $532 \mathrm{~nm}$ excitation laser with the intensity fixed at $4.906 \mathrm{~mW}$. This laser wavelength was used to detect the $\mathrm{C}-\mathrm{H}$ vibrational mode that appears as peaks or a broad peak in the range 2800 to $3100 \mathrm{~cm}^{-1}$, and the laser intensity was chosen to minimize damage to the sample. With the use of a $100 \times$ objective lens, the laser spot size (i.e., spatial resolution) approaches the diffraction limit of approximately $1 \mu \mathrm{m}$ in diameter. The laser was scanned over the $\mathrm{Si}$ wafer substrate containing the particle deposits with an automatically controlled X,Y piezoscanner stage. For each $750 \mathrm{~nm}$ step, a Raman spectrum was acquired with an exposure time of $10 \mathrm{~s}$ and five accumulations.

The compounds and minerals contained in the particles were identified by the main Raman-shift peaks in the spectral range $-100-4000 \mathrm{~cm}^{-1}$. The peaks were assigned to specific compounds and minerals by comparison with reported values from the literature (Tang and Fung, 1989; Ivleva et al., 2007; Freeman et al., 2008; Baustian et al., 2012; Laskina et al., 2013) and Raman databases. The peak positions were also verified by measuring standard pure chemical compounds using the current Raman system. The Raman-shift peak positions used for the identification of compounds and miner- als are summarized in Table 1. The identification of organic components was defined by detection of the $\mathrm{C}-\mathrm{H}$ vibrational mode that appears as peaks or a broad peak in the range 2800 to $3100 \mathrm{~cm}^{-1}$ (Baustian et al., 2012; Ault et al., 2013; Laskina et al., 2013). The strong broad peak obtained from atmospheric particles in the range 1200 to $1700 \mathrm{~cm}^{-1}$, such as that shown in Fig. 3a and c, is typically due to the presence of complex organic matter with conjugate double bounds, biological material, diesel soot, black and brown carbon, or humic-like substances (Escribano et al., 2001; Sadezky et al., 2005; Ivleva et al., 2007). Therefore, we refer to this broad peak as black or brown carbon (BBC) (Hiranuma et al., 2011). Other than peaks assigned to the specific components mentioned here, spectra showing strong fluorescence in the measured range, as shown in Fig. 3a, were further classified as "fluorescent particles".

Following the measurements under atmospheric pressure by AFM and micro-Raman, the particles on the Si wafer substrate were coated by Au with a thickness of approximately $30 \mathrm{~nm}$. The coated particles were located under SEM-EDX. The X-ray spectra were collected at $20 \mathrm{kV}$ acceleration voltage and $15 \mathrm{~mm}$ working distance. The relative atomic fractions $(\%)$ of the detected elements were determined by the ratios of the characteristic X-ray peak areas. Due to the limitations of the method, related to the quantification of lighter elements and elements contained in the coating and substrate, $\mathrm{C}, \mathrm{N}, \mathrm{O}, \mathrm{Au}$, and $\mathrm{Si}$ were excluded from the semi-quantitative analysis.

\section{Results}

\subsection{Observation of ice nucleation by IDFM}

Before evaluating the ice nucleation activity of the standard samples by IDFM, we measured the freezing temperature of pure water droplets using the same method, which can be regarded as the onset temperature of homogeneous freezing. As a result, homogeneous ice nucleation was initiated at approximately $-36.5^{\circ} \mathrm{C}$ or below, and all droplets spontaneously froze in a narrow temperature range within the same experimental run. All droplets froze before the temperature reached down to $-40^{\circ} \mathrm{C}$ in all experimental runs (Fig. S1). This homogeneous freezing temperature coincides with those reported by several previous laboratory experiments (Pruppacher and Klett, 1997; Murray et al., 2010,2012) and from observations of deep convective clouds (Rosenfeld and Woodley, 2000).

Heterogeneous ice nucleation observed in all standard mineral samples tested in this study (K-feldspar, Na-feldspar, quartz, kaolinite) consistently occurred at higher temperatures than the homogeneous freezing temperature. The reference mineral samples were milled to fine grains before being collected on Si wafer substrate by an impactor. Three sets of samples were made for each reference mineral to ensure a 
Table 1. Peak assignments for Raman spectra obtained in this study.

\begin{tabular}{lrl}
\hline & Raman peak assignments & \\
\hline & Raman shift $\left(\mathrm{cm}^{-1}\right)$ & Literature \\
\hline Feldspar & 485 & Freeman et al. (2008) \\
Quartz & 465 & Laskina et al. (2013) \\
$\mathrm{CaCO}_{3}$ & 1089 & Laskina et al. (2013) \\
$\mathrm{Na}_{2} \mathrm{CO}_{3}$ & 1080 & Hiranuma et al. (2011) \\
$\left(\mathrm{NH}_{4}\right)_{2} \mathrm{SO}_{4}$ & 975 & Tang and Fung (1989) \\
$\mathrm{CaSO}_{4}$ & 1005 & Hiranuma et al. (2011) \\
$\mathrm{Na}_{2} \mathrm{SO}_{4}$ & 990 & Tang and Fung (1989) \\
$\mathrm{NaNO}_{3}$ & 1069 & Tang and Fung (1989) \\
$\left.\mathrm{Mg} \mathrm{NO}_{3}\right)_{2} \cdot 6 \mathrm{H}_{2} \mathrm{O}$ & 1059 & Tang and Fung (1989) \\
$\mathrm{Ca}\left(\mathrm{NO}_{3}\right)_{2} \cdot 4 \mathrm{H}_{2} \mathrm{O}$ & 1050 & Tang and Fung (1989) \\
$\mathrm{C}-\mathrm{H}_{\text {vibration }}$ (organics) & $2800-3100$ & Baustian et al. (2012) \\
Black and brown carbon & $1200-1700$ & Ivleva et al. (2007) \\
Bonded OH stretch & $3200-3650$ & Baustian et al. (2012) \\
Fluorescent & -4000 & \\
\hline
\end{tabular}

large enough observation area for the IDFM. The total number of the particles monitored during the ice nucleation experiment by IDFM was 4509, 2271, 4759, and 1435 particles, respectively. In this study, the freezing onset temperature of the sample was defined as the temperature at which the IN active fraction of the total observed particles reached 0.01 . As a result, the freezing onset temperatures for K-feldspar, $\mathrm{Na}$-feldspar, quartz, and kaolinite ranged between -22.2 and $-24.2,-24.7$ and $-25.7,-24.8$ and -26.8 , and -27.2 and $-29.2^{\circ} \mathrm{C}$, respectively (Fig. S2). Therefore, the ice nucleation activity of K-feldspar was the highest and that of kaolinite was the lowest. The order and the range of observed onset temperatures for these minerals were consistent with the results found in the literature (Atkinson et al., 2013; Murray et al., 2011). For comparison, we also showed the IN activities of the reference samples in terms of ice nucleating active site (INAS) densities (Figs. S3 and S4), calculated based on the IN active fraction curve shown in Fig. S2 and the averaged sphere equivalent surface areas obtained from the 2-D silhouette of individual particles in the microscopic image.

The fact that the observed freezing temperatures were similar to those reported in previous studies clearly demonstrates the validity of the IDFM for representing immersionand condensation-mode ice nucleation. For comparison, the freezing onset temperatures of the ATD and ADS were - 22.1 to -23.7 and -25.2 to $-27.2^{\circ} \mathrm{C}$ for 2019 and 1354 monitored particles, respectively (Fig. S2; corresponding INAS densities estimated for ATD and ADS are shown in Fig. S4).

For ambient samples, we first determined the total number of target particles by analyzing the optical images recorded with $\times 50$ magnification. As a result, ice nucleation activity of 10188 and 24145 particles were monitored by the IDFM for the February and April samples, respectively. To avoid too many particles in contact or in proximity to each other in the same field of view, multiple samples were collected during the sampling period on separate silicon wafer substrates to gain a good total number of particles. Among those, the number of IN active particles was 37 for the February samples and 122 for the April samples. Therefore, the ice nucleation active fraction for $D_{\mathrm{p}}>1.1 \mu \mathrm{m}$ particles was $5.6 \times 10^{-3}$ for the April samples. This value is 1.5 times higher than that for the February samples $\left(3.6 \times 10^{-3}\right)$. While most of the IN active particles formed ice below $-28^{\circ} \mathrm{C}$, the highest onset temperature recorded for these ambient particles was $-25^{\circ} \mathrm{C}$. Particles with such a relatively high onset temperature tended to grow faster and larger, therefore coalescing with adjacent particles, complicating identification of individual particles following the ice nucleation experiment. As a result, individual analysis of such rapidly growing particles was not performed.

The advantage of IDFM is that we can keep track and be sure which of the collected single particles was actually nucleating ice. Thus, the IN active particles identified by IDFM can be studied in detail by various particle analysis techniques. Comparing IDFM with the other methods such as FRIDGE used primarily to measure ice nuclei concentration (Ardon-Dryer and Levin, 2014; Schrod et al., 2016, 2017), we have to compromise the accuracy and quantitative evaluation of IN activity since the evaporation of droplets around frozen particles by the Bergeron-Findeisen effect can affect the activated fraction. Therefore, by selecting the higher cooling rate and $-30^{\circ} \mathrm{C}$ as the end cooling temperature, we minimized the evaporation and the scavenging of the droplets around the rapidly growing ice crystals in the experiments of atmospheric particles. This way, most of the atmospheric particles (excluding those very close to the ice crystals) were not dried and remained as droplets until temperature reached $-30{ }^{\circ} \mathrm{C}$. Note, however, that the selected cooling rate is con- 
AFM

(a)

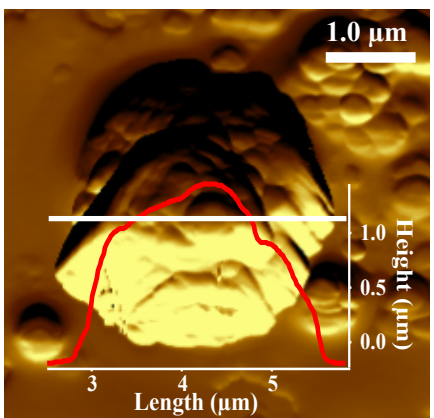

(b)

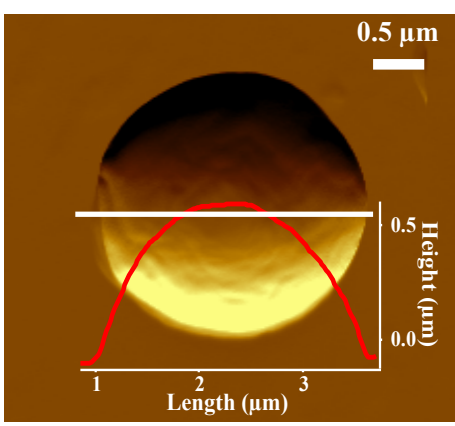

(c)

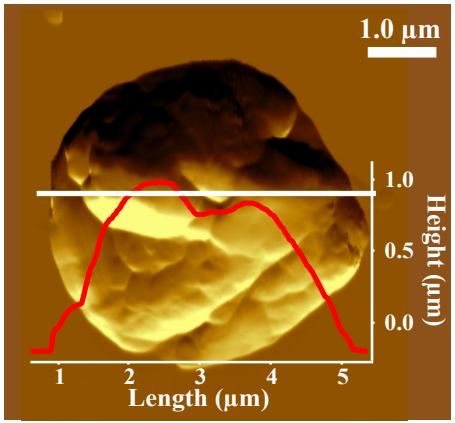

Micro-Raman
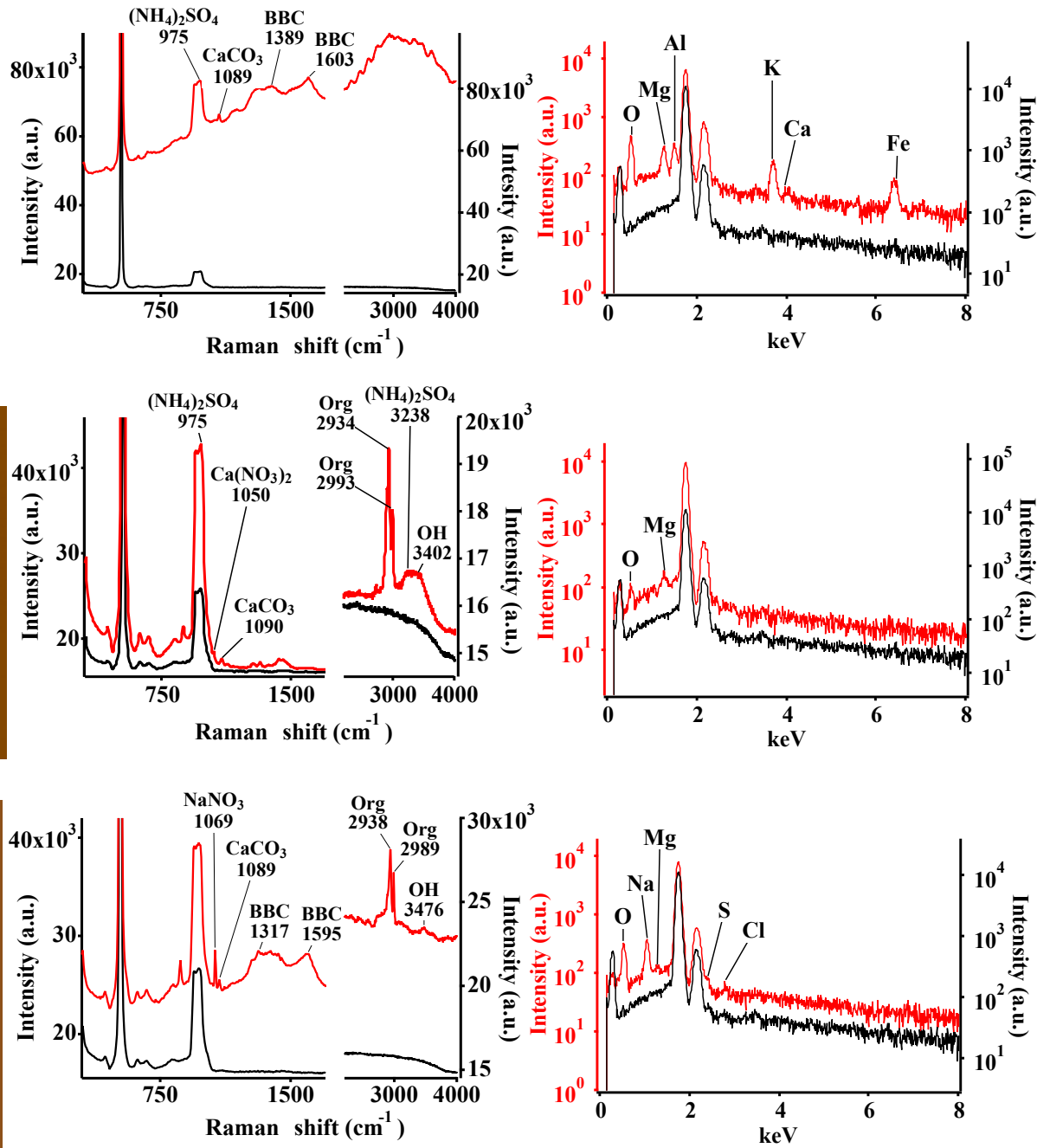

EDX

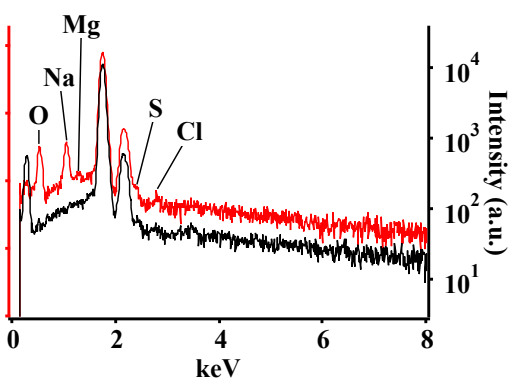

Figure 3. AFM topographic images of representative IN active particle (a) and non-active particle (b, c) groups, and their corresponding Raman and EDX spectra. The AFM images were obtained in probe amplitude mode. The inset in the AFM image shows the scanned height along the white transect of each particle. The red and black curves indicate the spectra of the particles and the substrate background, respectively.

siderably faster when compared with the typical cooling rate found in the convective cloud updraft. Also, we cannot fully rule out the possibility that droplets very close to an ice crystal may have been fully evaporated.

With respect to the particle size detection/limit, the impactor already size segregates particles and limits the test particles in the supermicron range. The diameter of the collected atmospheric particles whose ice crystal formation could be monitored ranged between 1.16 and $5.47 \mu \mathrm{m}$ through the identification by the optical microscope. Meanwhile, the laser spot size (i.e., spatial resolution) of micro-Raman spectroscopy approaches the diffraction limit of approximately $1 \mu \mathrm{m}$ in diameter. All in all, the size of IN active particles that can be analyzed by this method is limited to supermicron particles.

\subsection{Observation of individual IN active particles by AFM}

Due to the inherently small number of IN particles in the atmosphere, three different analytical methods were employed to gather as many physical and chemical characteristics as possible from individual IN active particles.

Firstly, the 3-D morphological images and the maximum height $(h)$ based on the cross-sectional shape of 22 IN active particles and 67 non-active particles were obtained by 
(a)

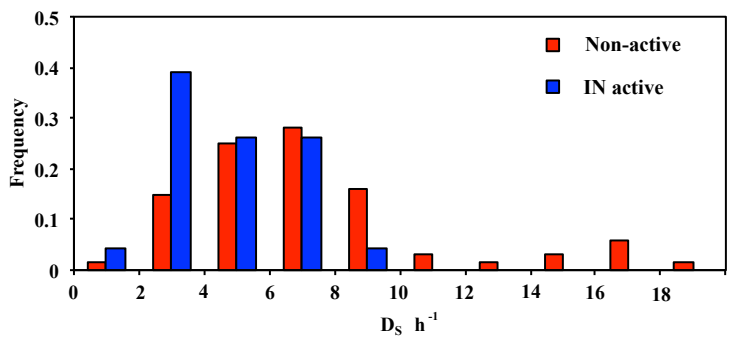

(b)

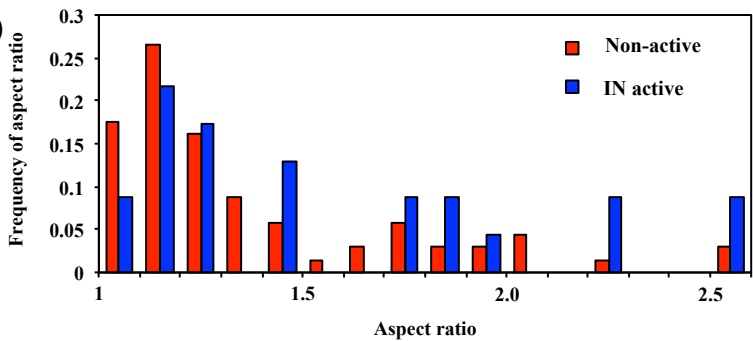

Figure 4. Frequency distributions of $D_{\mathrm{S}} / h$ (a) and aspect ratio (b) for non-active and IN active particles from AFM observation.

AFM (note that the counts are shown as the sum of February and April samples due to the small number of IN active particles). We further determined the surface equivalent diameter $\left(D_{\mathrm{S}}\right)$, which is defined as the arithmetic average of the longest axis and its orthogonal axis in the 2-D particle silhouette. As a result, the IN active particles were found to fall within the $1.12-14.60 \mu \mathrm{m}$ range for $D_{\mathrm{S}}$ and in the 0.32 $3.28 \mu \mathrm{m}$ range for $h$, while the non-active particles had $D_{\mathrm{S}}$ values of $0.60-12.04 \mu \mathrm{m}$ and $h$ values of $0.07-1.98 \mu \mathrm{m}$.

In terms of particle shape, we determined the $D_{\mathrm{S}} / h$ ratio, which can be closely linked to the physical state, whereby semi-ellipsoidal particles with high $D_{\mathrm{S}} / h$ ratios tend to be in a liquid or semi-liquid state, while irregular-shaped particles with low ratios are most likely in a dry solid phase (Sobanska et al., 2014). As shown in Fig. 4a, while the IN active particles tended to concentrate in low $D_{\mathrm{S}} / h$ ratios, the nonactive particles showed a wider range, including relatively high $D_{\mathrm{S}} / h$ ratios. This suggests that the IN active particles were predominantly irregular solid particles.

Aspect ratio was also determined for each particle using the ratio between the major and minor axes of the best-fit ellipse of the 2-D particle silhouette. Although the number of measured particles was small, the aspect ratio of the IN active particles was not close to 1 (Fig. 4b). In other words, the IN active particles were predominantly irregularly shaped particles (as shown in Fig. 3a), consistent with the results of $D_{\mathrm{S}} / h$ ratio distribution (Fig. 4a). Conversely, the particles shown in Fig. $3 b$ and $c$ were more representative of non-active particles. It is noteworthy, however, that the analyzed morphology of particles may not necessarily correspond to that in the actual atmosphere, since particles can be flattened upon impaction and particle shape can also be altered following ice

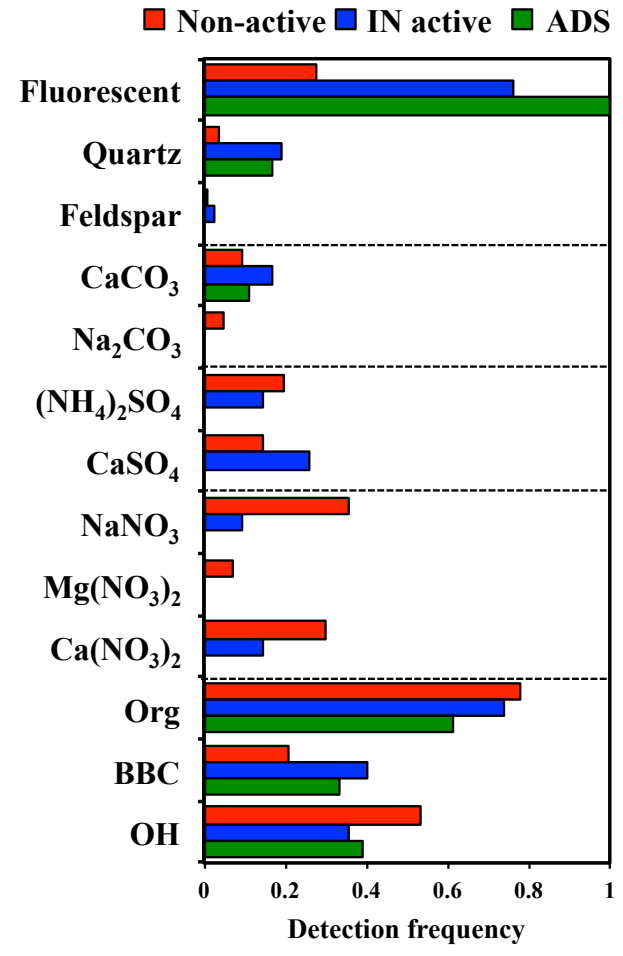

Figure 5. Summary of the detection frequencies of the assigned components in non-active and IN active particles by micro-Raman analysis. Data from ADS particles are shown for comparison.

nucleation experiments involving ice and/or droplet activation.

\subsection{Analysis of individual IN active particles by micro-Raman spectroscopy}

Chemical species contained in the $42 \mathrm{IN}$ active particles and 131 non-active particles were identified by Raman spectra mapping (counts include the February and April samples combined). The detection frequencies of the Raman-active molecular compounds among individual particles are summarized in Fig. 5.

It was found that more than $70 \%$ of both IN active particles and non-active particles contained organic matter. Additionally, nitrate and/or sulfate peaks were detected in 50 and $99 \%$ of the IN active and non-active particles, respectively. These results show that most of the ambient aerosol particles $\left(D_{\mathrm{p}}>1.1 \mu \mathrm{m}\right)$ collected in this study were internally mixed with organic and/or inorganic (sulfate and nitrate) materials.

The fraction of particles containing sulfates, such as $\left(\mathrm{NH}_{4}\right)_{2} \mathrm{SO}_{4}$ and/or $\mathrm{CaSO}_{4}$, was 40 and $34 \%$ for IN active and non-active particles, respectively. Moreover, a significantly larger fraction (76\%) of the IN active particles showed fluorescence in the Raman spectra. Fluorescence from a particle is typically attributed to a certain group of organics of biological origin, or the intercalated impurities of humic or 
humic-like substances in clay minerals and amorphous aluminosilicates (Sobanska et al., 2012; Jung et al., 2014). In addition to the fraction of fluorescent particles, $\mathrm{BBC}, \mathrm{CaSO}_{4}$, and quartz were detected in the IN active particles with significantly higher frequencies than in non-active particles. In contrast, the particles indicating broad $\mathrm{OH}$ peaks and nitrate peaks were more abundant in non-active particles. In terms of the detection frequency of organic matter and $\left(\mathrm{NH}_{4}\right)_{2} \mathrm{SO}_{4}$, we did not find any clear differences between IN active and non-active particles.

We also performed micro-Raman analysis on ADS particles for comparison. As shown in Fig. 5, all ADS particles showed fluorescence in the Raman spectra. Organic matter and quartz components were identified in 61 and $16 \%$ of individual ADS particles, respectively. Meanwhile, peaks indicating sulfates or nitrates were not detected in any ADS particles. This is consistent with the findings that Asian dust aerosols near the source region are fresher and hence contain less sulfur than in the downwind regions (Trochkine et al., 2003). This result clearly indicates that many mineral dust particles are originally internally mixed with organic matter to some extent, but that the Asian dust source does not contain sulfates or nitrates (Kawamura et al., 2004).

Additionally, the presence of feldspar in the individual particles was tested by comparing spectra with those of the standard mineral samples. However, there were almost no particles showing typical spectra indicating the presence of feldspar in the ambient samples. The possibility remains that the feldspar content was so small that it was below detection limits, or that the feldspar contained impurities or had defects in the crystal structures that may have caused interference in the form of strong fluorescence in the Raman spectrum. Nonetheless, we did not observe any particles predominantly composed of pure feldspar, such as the standard feldspar sample, that indicated characteristic peaks in the Raman spectra.

\subsection{Analysis of individual IN active particles by SEM-EDX}

Elemental compositions of 37 IN active and 114 non-active particles were analyzed using SEM-EDX (counts include the February and April samples combined). The presence of mineral dust particles can be identified by the dominant $\mathrm{X}$-ray peaks corresponding to $\mathrm{Al}, \mathrm{Mg}$, and $\mathrm{Fe}$. Due to interference by the Si wafer substrate, Si was not determined in this study. The particles predominantly composed of $\mathrm{Na}$ and $\mathrm{Cl}$ were classified as fresh sea salt with a $\mathrm{Cl} / \mathrm{Na}$ ratio in the $0.8-1.2$ range. Due to the $\mathrm{Cl}$ liberation reaction during transport (Zhang et al., 2003), those particles with a lower $\mathrm{Cl} / \mathrm{Na}$ ratio can be considered as aged sea salt particles. Particles enriched in $\mathrm{Ca}$ or $\mathrm{S}$ were classified as Ca-rich particles or sulfate particles, respectively. When a particle contained more than $35 \%$ of elements other than the predominant com-
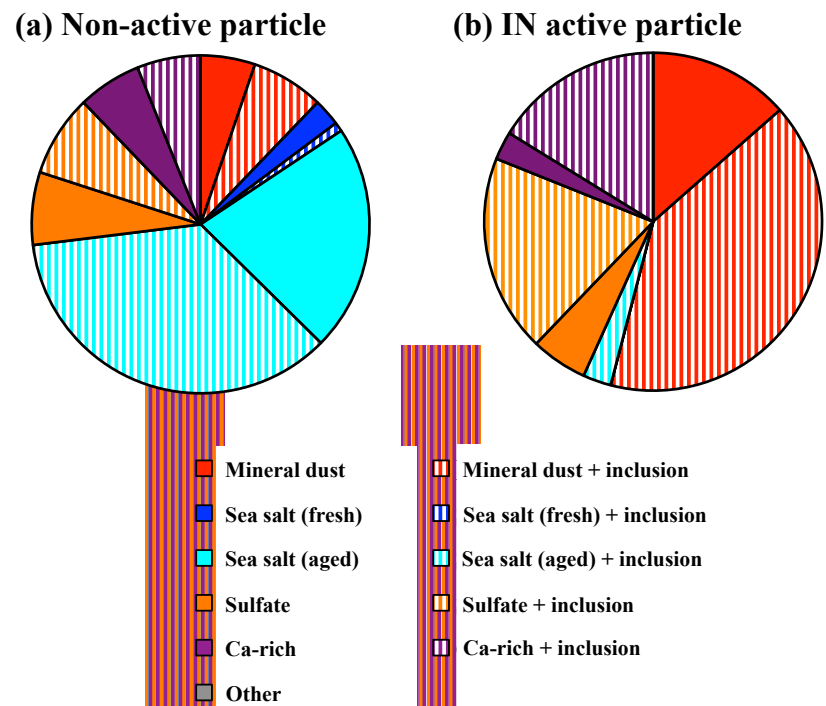

Figure 6. Relative abundance of the particle groups identified by SEM-EDX for non-active (a) and IN active particles (b). April and February samples are combined.

ponents, we defined it as an internal mixture, which is designated by "+ inclusion" in Fig. 6.

As shown in Fig. 6, the relative abundance of particle groups clearly differed between IN active and non-active particles. The mineral dust particle groups (mineral dust and mineral dust + inclusions) accounted for $55 \%$ of IN active particles and were the most dominant type, while sea salt particles were rarely found (3\%). Conversely, the majority (62\%) of non-active particles was dominated by fresh and aged sea salt particles, suggesting it was internally mixed with other components, such as S. The mineral dust particle group, in turn, comprised a relatively minor fraction (12\%). Note, however, that elements $\mathrm{C}, \mathrm{N}, \mathrm{O}$, and $\mathrm{Si}$ were not taken into account in the EDX semi-quantitative analysis. Therefore, we cannot rule out the possibility that organic dominant particles may be overlooked by EDX analysis alone.

The Ca-rich and sulfate groups were found in both IN active and non-active particles. However, the pure Ca-rich and sulfate component groups were relatively minor compared to internal mixtures, which contain the latter components plus other matter ( + inclusion), for IN active particles. They were found in similar fractions for non-active particles.

Particles enriched in $\mathrm{Pb}$ (lead) were reported to be involved in the formation of ice crystals at Jungfraujoch (Cziczo et al., 2009). However, such particles enriched in $\mathrm{Pb}$ were neither found in IN active particles nor in non-active particles.

The semi-quantitative comparison of particle composition obtained by micro-Raman spectroscopy and SEM-EDX analyses is hampered by the different principles employed in the two techniques. Particle classification with SEM-EDX relies on characteristic X-ray signals, which are used to estimate the major elemental composition of a particle. This 
information can be considered to reflect the bulk elemental distribution within a particle and has been commonly used for particle classification in many previous studies. In contrast, micro-Raman spectroscopy detects slight shifts of wavelength in the scattered light that reflect the vibrations of molecular bonds specific to the compounds contained in a sample. Therefore, the Raman spectrum was used rather to complement the bulk particle type classification by the EDX analysis and to detect the internally mixed compounds.

\section{Discussion}

\subsection{Mineral dust particles}

The SEM-EDX analysis indicated that mineral dust particles accounted for $55 \%$ of the IN active particles (Fig. 6). Fluorescent particles identified by micro-Raman spectroscopy were also common (76\%) in IN active particles (Fig. 5). Subsequent SEM-EDX analysis showed that most of the fluorescent particles $(87 \%)$ contained elements that indicate a mineral composition. The fluorescence is also often taken as an indication for the presence of biological aerosols (Twohy et al., 2016), but considering the fact that all the ADS particles also showed similar fluorescence, and the relatively small abundance of biological particles as compared to mineral dust in general (Huffman et al., 2012), these fluorescence signals are mostly associated with mineral dust (especially those enriched in clay minerals) rather than pure biological particles. The possibility remains, however, that a fraction of the fluorescence signal results from biological matters attached to the clay minerals. In any case, both the SEM-EDX and micro-Raman analyses indicated that mineral dust particles act as efficient ice nuclei under conditions relevant for mixed-phase cloud formation.

This finding is in good agreement with the findings of previous work. For example, several laboratory studies showed that mineral dust particles are capable of nucleating ice crystals at relatively high temperatures and may be important ice nuclei, especially at temperatures below approximately $-15^{\circ} \mathrm{C}$ (Murray et al., 2012). Additionally, several in situ field studies performed within a mixed-phase cloud at Jungfraujoch, a high-elevation site in the Swiss alpine region, reported that mineral dust was the most abundant component, comprising $40-70 \%$ of the ice residue particles by number (Worringen et al., 2015; Ebert et al., 2011; Kamphus et al., 2010).

Nonetheless, questions remain concerning the factors controlling the IN properties of mineral dust. These particles exist as internal mixtures of several minerals. Strictly speaking, therefore, the mineralogical composition of mineral dust is unique to each particle. Recently, several studies have pointed out that the feldspar group, especially K-feldspar, is an important mineral component for ice nucleation within mixed-phase clouds at higher temperatures (Atkinson et al.,

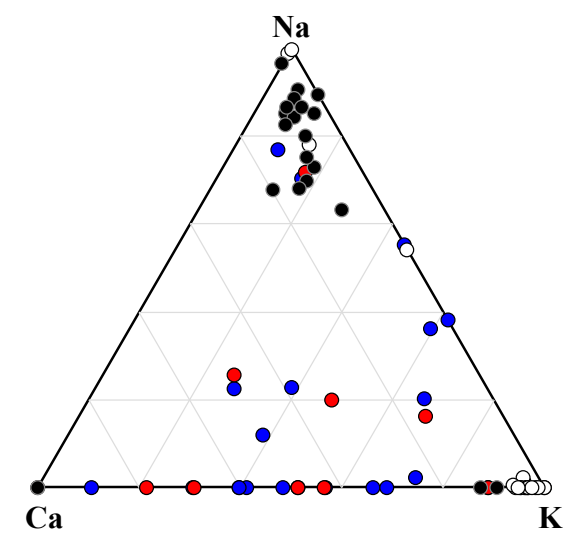

Figure 7. Ternary diagram of $\mathrm{Na}-\mathrm{Ca}-\mathrm{K}$ components, showing the compositions of mineral dust particles identified by SEM-EDX analysis. Data are presented in relative atomic proportions. The circles indicate non-active particles (red) and IN active particles (blue). Particles of Na-feldspar (black) and K-feldspar (white) are also shown for comparison.

2013; Harrison et al., 2016; Boose et al., 2016). Also, quartz has been proposed to contribute to the relatively strong ice nucleation activity of natural desert dusts (Boose et al., 2016), whose stronger ice nucleation activity in immersion mode than that of clay minerals is thought to be related to defects present on the surface of quartz particles (Zolles et al., 2015).

In this study, standard K-feldspar $\left(-20.3^{\circ} \mathrm{C}\right)$ and quartz $\left(-25.7^{\circ} \mathrm{C}\right)$ samples were indeed more efficient ice nuclei than ADS particles $\left(-26.6^{\circ} \mathrm{C}\right)$. However, most of the collected atmospheric particles formed ice crystals at temperatures below $-25^{\circ} \mathrm{C}$. These ice nucleation onset temperatures are similar to those reported for several natural dust samples from different regions around the world (Boose et al., 2016; Kaufmann et al., 2016).

The mineral dust particles can be further separated into $\mathrm{K}$-feldspar and $\mathrm{Na} / \mathrm{Ca}$-feldspar groups using a $\mathrm{Na}-\mathrm{Ca}-\mathrm{K}$ ternary plot (Fig. 7). Mineral particles composed mainly of other clay minerals and mica should appear near the center of the Al-K-(Ca+Na) ternary plot (Fig. S5). However, K-feldspar-dominated particles were rarely observed in the atmospheric mineral dust particles analyzed in this study, although $\mathrm{Na} / \mathrm{Ca}$-feldspar (plagioclase feldspar), mica, and clay minerals were present. Also, peaks of feldspar (2\%) or quartz (19\%) were rarely identified in the Raman spectra of the analyzed mineral dust particles, further suggesting the absence of K-feldspar enriched particles. Even where feldspar and quartz peaks were observed, they also contained other mixtures such as fluorescent material, organic matter, or sulfates, which were not particularly IN active. Therefore, highly IN active dust particles composed of single-component minerals, such as feldspar or quartz, were very rare or non-existent in the ambient aerosols collected in this study. Although we may have miscounted some 
IN active particles due to the aforementioned coalescence with adjacent particles during ice crystal growth, even the most rapidly growing crystals initiated ice nucleation below $-25^{\circ} \mathrm{C}$. Thus, it would have been noticed if particles as active as the standard K-feldspar were nucleating at higher temperatures.

A previous study has reported that clay and mica account for $51 \%$ of the Asian dust particles over Japan, while quartz $(10 \%)$ and feldspar $(5 \%)$ are minor mineral components, based on similar identification criteria to those employed in this study (Iwasaka et al., 2009a). Simulated Asian mineral dust has also been investigated, and the detection frequency of K-feldspar was significantly lower (2\%) than that of $\mathrm{Na} / \mathrm{Ca}$-feldspar (12\%) (Yabuki et al., 2002). The results of onset temperature and related particle mineralogy (both in terms of SEM-EDX and micro-Raman spectroscopy), suggested that IN mineral dust particles as efficient as pure component K-feldspar or quartz are extremely rare in the atmosphere (at least in east Asia, which is affected by Asian dust). Furthermore, we even found that all the fresh ADS particles (believed to be dominated largely by clay minerals) showed the fluorescence. This fluorescence is likely derived from the defects and/or impurities (e.g., humic organics) in their crystal structure (Gaft et al., 2005; Jung et al., 2014; Sovanska et al., 2014). Therefore, the fluorescent particles associated with elements of crustal origin (by EDX analysis) were regarded as clay minerals. It was also demonstrated that the most IN particles active above $-30^{\circ} \mathrm{C}$ were dominated by such fluorescent mineral dust particles.

More recently, Kaufmann et al. (2016) found no significant differences between the freezing temperatures of dust samples collected from ground soil of various arid dust source regions. Mineral components with extremely high ice nucleation activity, such as the alkali feldspar microcline, were found only as minor components. Their results further suggested that dust mixing in the natural environment reduces high ice nucleation efficiency (Kaufmann et al., 2016). Additionally, minerals in the natural environment are decomposed by reactions with water (chemical weathering processes), thus forming Al-rich clay minerals. Our results are consistent with these findings, such that the distribution of freezing temperatures of the studied natural dusts is much more compact and falls within a narrower temperature range than that reported for a variety of reference minerals. It is worth noting that our results are based on actual atmospheric aerosol samples rather than sieved surface soil, and that the freezing experiment and characterization were made on a singleparticle basis by the coupling of IDFM, micro-Raman spectroscopy, and SEM-EDX. Therefore, our results should be representative of the ice nucleation activity expected within mixed-phase clouds.

\subsection{Sea salt particles}

While mineral dust particles were found with the highest frequency among the particles that nucleate ice crystals, sea salt particles were the most dominant particle type in non-active particles (Fig. 6).

Although sea salt particles were assigned based on the largest atomic concentration of $\mathrm{Na}$ and $\mathrm{Cl}$ by EDX analysis, many particles had a combined $\mathrm{Na}$ and $\mathrm{Cl}$ concentration of less than $65 \%$ with low $\mathrm{Cl} / \mathrm{Na}$ ratios. Note, however, that this elemental fraction of sea salt components is based on SEM-EDX and does not reflect potential contribution from organics and therefore must be regarded as the upper limit. This is an indication that many sea salt particles were aged and mixed with other components. In EDX analysis, in particular, most of these sea salt mixtures were characterized by a large $\mathrm{S}$ fraction, indicating that they were internally mixed with sulfates. Moreover, those particles showed peaks of organic matter, sulfates, or nitrates (in particular $\mathrm{MgNO}_{3}$ ) in the Raman spectra. Therefore, these particles can be considered as aged sea salt particles that were internally mixed with nitrates, sulfates, or organics. The freezing experiments clearly demonstrated that these aged sea salt particles are not efficient ice nuclei in mixed-phase cloud formation.

Ice nucleation by sea salt particles has been suggested by previous field studies but under conditions relevant for cirrus cloud formation instead (Cziczo et al., 2013). Meanwhile, ice nucleation by sea salt particles under mixed-phase cloud conditions has not been fully confirmed by previous field studies, due to the geographical limitation of research facilities and technical difficulties related to the direct collection of ice residue particles (Worringen et al., 2015). Laboratory studies have reported ice nucleation by crystalline sea salt at much lower temperatures (Wise et al., 2012). Recently, Wilson et al. (2015) reported that sea spray organic aerosols derived from the sea surface microlayer nucleate ice under conditions relevant for mixed-phase clouds and ice cloud formation at high altitudes, but the sea water itself did not contribute markedly to ice nucleation. Based on the results of this study, we suggest that large and aged sea salt particles internally mixed with sulfates, nitrates, or organics are less likely to nucleate ice, although the possibility remains for ice nucleation by sea spray organic particles in the atmosphere. The lower freezing temperature of $\mathrm{NaCl}$ solution relative to pure water droplets (Fig. S1) and the degree of dilution (Table S1) involved in the experiment suggest that the weak IN activity of sea salt particles could be explained by the molar depression of freezing point by the soluble salt.

A ternary diagram of $\mathrm{Na}-(\mathrm{Al}+\mathrm{Mg}+\mathrm{Fe})-(\mathrm{Ca}+\mathrm{S})$ showing the compositions of all analyzed particles is shown in Fig. 8. Interestingly, the diagram clearly indicates that particles with $\mathrm{Na}$ greater than $35 \%$ were dominant amongst non-active particles. This indicates that internal mixing with sea salt may act as an important inhibiting factor for ice nucleation within mixed-phase clouds. For example, particles 


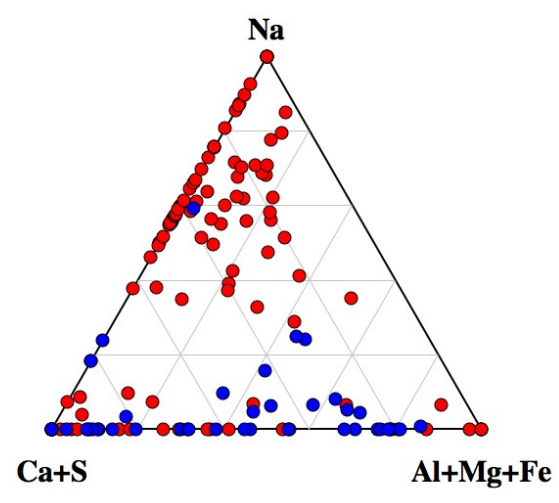

Figure 8. Ternary diagram of $\mathrm{Na}-(\mathrm{Ca}+\mathrm{S})-(\mathrm{Al}+\mathrm{Mg}+\mathrm{Fe})$ components, showing the compositions of all particles analyzed by SEMEDX analysis. Data are presented in relative atomic proportions. The circles indicate the non-active (red) and IN active particles (blue).

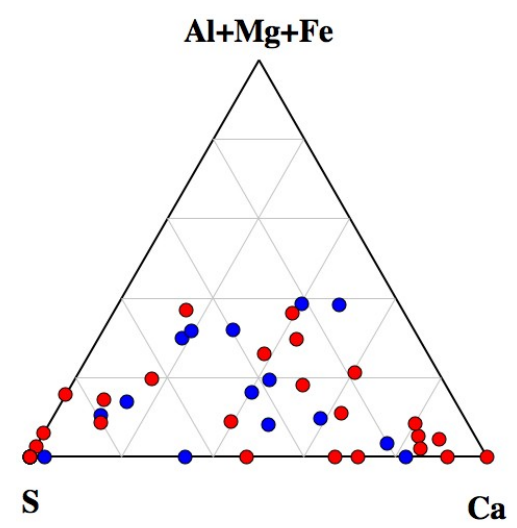

Figure 9. Ternary diagram of $(\mathrm{Al}+\mathrm{Mg}+\mathrm{Fe})-\mathrm{S}-\mathrm{Ca}$ for $\mathrm{Ca}-\mathrm{rich}$ and sulfate particles analyzed by SEM-EDX analysis. Data are presented in relative atomic proportions. The circles indicate the nonactive (red) and IN active particles (blue).

containing mineral dust components (often found among IN active particles), showing clear mixing with sea salt, were rarely found among IN active particles but were rather common in the non-active particle group.

\subsection{Ca-rich and sulfate particles}

As shown in Fig. 6, both relatively pure Ca-rich particles and sulfate particles (without inclusions) were detected with similar frequencies among the IN active and non-active particles. The particles enriched in $\mathrm{Ca}$ can be related to mineral dusts such as calcite $\left(\mathrm{CaCO}_{3}\right)$, dolomite $\left(\mathrm{CaMg}\left(\mathrm{CO}_{3}\right)_{2}\right)$, and gypsum $\left(\mathrm{CaSO}_{4}\right)$. Calcite- or dolomite-dominated particles can be inferred by the elemental ratio of $\mathrm{Mg} / \mathrm{Ca}$ (calcite: $\mathrm{Mg} / \mathrm{Ca}<0.5$, dolomite: $\mathrm{Mg} / \mathrm{Ca}>0.5$ ). The presence of pure gypsum can be inferred from the $\mathrm{S} / \mathrm{Ca}$ ratio of 1 in the Ca-rich particle group (Trochkine et al., 2003), but a $\mathrm{S} / \mathrm{Ca}$ ratio of $<1$ is expected because gypsum is typi- cally regarded as occurring in a mixture with calcite (Iwasaka et al., 2009a). The dolomite-dominated particles with high $\mathrm{Mg}$ contents were rare among the Ca-rich particles. Most of the Ca-rich particles were classified as calcite or gypsum with $\mathrm{Mg}$ as a minor component.

There seems to be no marked difference between the IN active and non-active Ca-rich particles in terms of their mixing states with other mineral components (e.g., $\mathrm{Al}, \mathrm{Mg}, \mathrm{Fe}$ ) from the SEM-EDX analysis (Fig. 9). Interestingly, however, Ca-rich particles with small $\mathrm{S}$ content $(\mathrm{S} / \mathrm{Ca}<0.2)$, which can be regarded as predominantly calcite, were more common in non-active particles (i.e., bottom right corner in Fig. 9). Of the non-active Ca-rich particles, $50 \%$ were detected with a carbonate peak in the Raman spectra, confirming the presence of calcite. In contrast, carbonate peaks were hardly detected in Ca-rich particles in the IN active group. In terms of compounds identified by micro-Raman analysis, the detection frequencies of fluorescence, sulfates, or organic matter among Ca-rich particles were difficult to compare as no obvious differences were found between the IN active and non-active particles. Meanwhile, nitrate peaks, in particular the $\mathrm{Ca}\left(\mathrm{NO}_{3}\right)_{2}$ peak, were more frequently detected in nonactive particles than in IN active Ca-rich particles. In other words, we suggest that $\mathrm{Ca}$-rich particles mixed with nitrates are less likely to form ice than Ca-rich particles mixed with organics and sulfates.

Frequent detection of $\mathrm{Ca}\left(\mathrm{NO}_{3}\right)_{2}$ has several important implications related to the physical state of the Ca-rich particles in the atmosphere. It is reported that originally solid Ca-rich $\left(\mathrm{CaCO}_{3}\right)$ particles readily deliquesce and are converted into aqueous droplets following the atmospheric reaction with gaseous $\mathrm{HNO}_{3}$ to form $\mathrm{Ca}\left(\mathrm{NO}_{3}\right)_{2}$ (Laskin et al., 2005; Matsuki et al., 2005). Indeed, we found that the aspect ratios of non-active $\mathrm{Ca}$-rich particles measured by AFM tended to show smaller values closer to 1 . Furthermore, AFM topographic images of such particles typically showed thin coatings around the core (core-shell structure) as shown in Fig. 10b, very much resembling the morphological features of the Ca-rich aqueous droplets described in the literature. Note also that the core of the particle showed a peak for $\mathrm{Al}$ in the EDX spectra, suggesting the presence of aluminosilicate (e.g., clay) particle in the center. Such Ca-rich spherical particles were exclusively found among non-active particles rather than the IN active Ca-rich particles (Fig. 10a), suggesting that nitrate-containing $\mathrm{Ca}$-rich spherical particles are less likely to act as ice nuclei in the mixed-phase clouds. It is worth pointing out that $\mathrm{Ca}\left(\mathrm{NO}_{3}\right)_{2}$ is an extremely soluble salt with a solubility of $121.2 \mathrm{~g} / 100 \mathrm{~g} \mathrm{H}_{2} \mathrm{O}$ at $20^{\circ} \mathrm{C}$. Therefore, the liquefied $\mathrm{Ca}\left(\mathrm{NO}_{3}\right)_{2}$ coating is expected to show strong molar depression of freezing point, which could explain their weak IN ability (Table S1). These Ca-rich spherical particles mixed with nitrates were found to be less IN active than Carich particles mixed with organics or sulfates, regardless of the composition of their core particles (e.g., with or without clay mineral particles). Tobo et al. (2010) reported sim- 
AFM

(a)

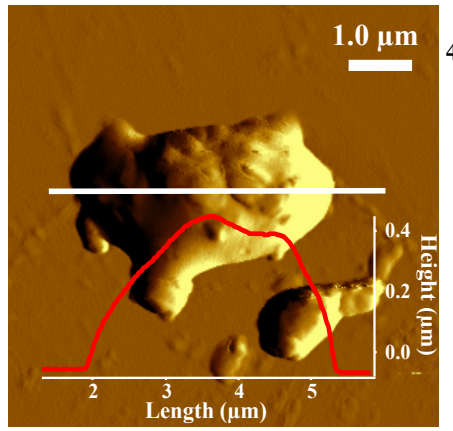

(b)

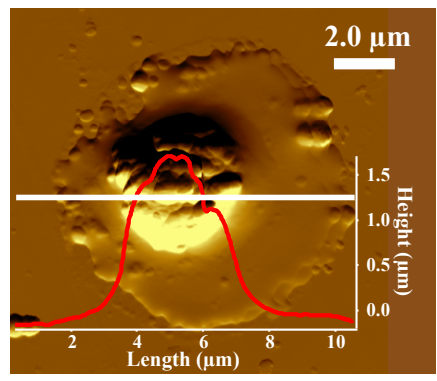

Micro-Raman
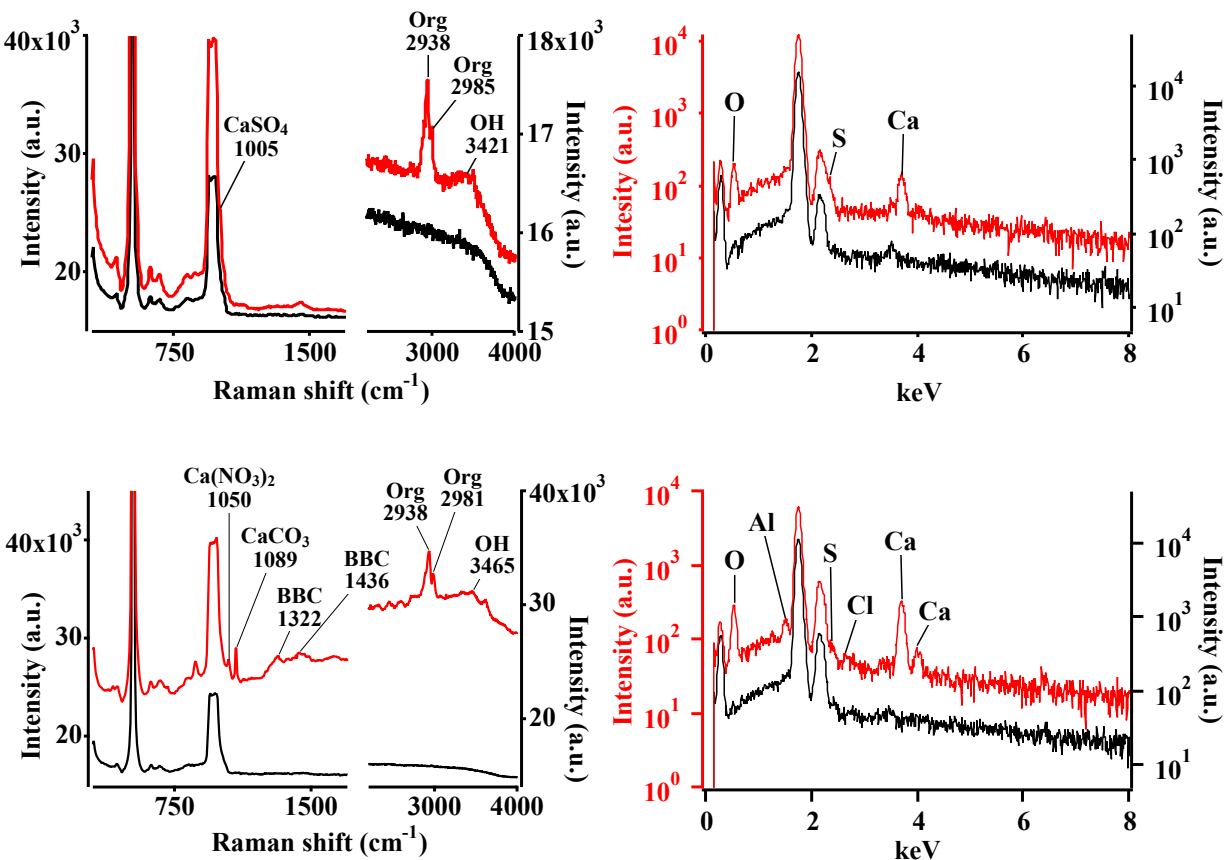

EDX

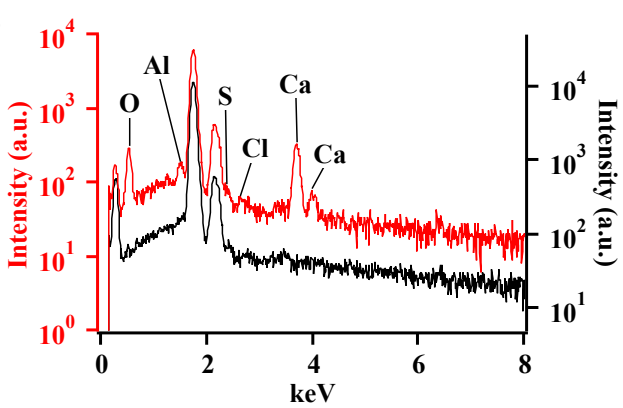

Figure 10. AFM topographic images of representative Ca-rich particles in IN active (a) and non-active (b) groups, and their corresponding Raman and EDX spectra. The AFM images were obtained in probe amplitude mode. The inset in the AFM image shows the scanned height along the white transect of each particle. The red and black curves indicate the spectra of the particle and the substrate background, respectively.

ilar liquefied particles can be formed through reaction with gaseous $\mathrm{HCl}$ to form $\mathrm{CaCl}_{2}$. Such chloride particles are also expected to behave similarly to the Ca-rich particles having $\mathrm{Ca}\left(\mathrm{NO}_{3}\right)_{2}$.

There is still a slight discrepancy among previous studies concerning the ice nucleation activity of carbonates. For example, several laboratory studies regarded calcite as an inefficient ice nucleus (Murray et al., 2012; Atkinson et al., 2013), while one laboratory experiment and field study reported that Ca-rich particles act as ice nuclei (Zimmermann et al., 2008; Worringen et al., 2015). Although the number of analyzed particles is rather small, our result suggests that pure calcite (i.e., fresh) particles or their mixture with nitrate are less likely to nucleate ice under mixed-phase cloud conditions.

Particles with $\mathrm{S} / \mathrm{Ca}>0.8$ were grouped into sulfate particles. In terms of elemental composition determined by SEMEDX analysis, there were no differences between the sulfatedominated particles that were IN active and non-active. However, from the micro-Raman analysis, $43 \%$ of non-active sulfate particles showed a peak of $\left(\mathrm{NH}_{4}\right)_{2} \mathrm{SO}_{4}$, while none of the IN active sulfate particles showed this peak. Particles identified as $\mathrm{CaSO}_{4}$, or those with fluorescent peaks, showed a relatively higher abundance among IN active particles.
Sulfate particles are generally believed to nucleate ice crystals only under cirrus-forming conditions (Abbatt et al., 2006). However, field studies have reported the presence of sulfate particles in ice residue, although potential bias from sampling artifacts cannot be entirely excluded (Prenni et al., 2009; Worringen et al., 2015; Ebert et al., 2011).

With regard to the Ca-rich and sulfate particles studied here, in summary, our results suggest that $\left(\mathrm{NH}_{4}\right)_{2} \mathrm{SO}_{4}$, intact calcite, or Ca-rich spherical particles mixed with nitrates in the atmosphere are less likely to nucleate ice. Meanwhile, Ca-rich particles with internally mixed sulfate (e.g., $\mathrm{CaSO}_{4}$ ), or sulfate-dominated particles internally mixed with clay minerals, may have a higher chance of nucleating ice under mixed-phase cloud formation conditions.

\subsection{Organic matter}

Various forms of organic matter are believed to be involved in ice nucleation. For example, some primary biological particles such as bacteria and pollen can act as efficient ice nuclei (Möhler et al., 2008a; Pummer et al., 2012; Hara et al., 2016). Soot particles and humic-like substances also act as ice nuclei in immersion mode, although with variable freezing temperatures (Diehl and Mitra, 1998; DeMott et al., 1999; Brooks et al., 2014; O'Sullivan et al., 2014). Based 
on Raman spectroscopy, $70 \%$ of particles showed the broad peak indicating the presence of organic matter in both the IN active and non-active particles analyzed in this study. The frequent detection of organic matter in this study is in agreement with other field measurements on atmospheric particles (Baustian et al., 2012).

Particles detected with and without organic matter showed no significant difference in terms of the particle groups and their fractions identified by SEM-EDX for both IN active and non-active particles. This implies that the organics detected in this study had a secondary effect on ice nucleation above $-30^{\circ} \mathrm{C}$, or simply that the current definition of organic matter (based on the $\mathrm{C}-\mathrm{H}$ stretching band alone) is not capable of resolving IN active and non-active compounds.

In the Raman analysis, $98 \%$ of particles detected with a broad peak arising from the intermolecular hydroxyl groups $\left(3200-3650 \mathrm{~cm}^{-1}\right)$ were associated with particles containing the organic matter peak $(\mathrm{C}-\mathrm{H})$. It is worth noting that a similar association of hydroxyl groups with organic matter was reported for IN particles under cirrus cloud conditions (Baustian et al., 2012). The detected $\mathrm{OH}$ broad peaks associated with organic matter are not as strong as the Raman intensities from water typically observed with particle deliquescence and therefore clearly distinguishable. As shown in Fig. 5, non-active particles (53\%) showed a higher detection frequency of organic particles with $\mathrm{OH}$ broad peaks than IN active particles (39\%).

Past laboratory studies reported that biomass burning particles, organic acid, and secondary organic particles have the potential to nucleate ice in the conditions relevant for cirrus cloud formation (Petters et al., 2009; Prenni et al., 2009b; Hoose and Möhler, 2012). Möhler et al. (2008b) suggested that thick coatings of organic matter can inhibit the depositional freezing of mineral dust. Moreover, the ice nucleation activity of mineral dust particles is enhanced due to mixing with heat-sensitive organic substances supposedly of biological origin (Conen et al., 2011; Tobo et al., 2014). The ice nucleation activity of oxidized organic matter has also been reported from several laboratory experiments and field studies but for conditions of cirrus cloud formation (Knopf et al., 2010; Baustian et al., 2012). In this respect, the effects of mixing with either oxidized or non-oxidized organic matter on ice nucleation in mixed-phase clouds have not been fully confirmed, either by laboratory or field experiments.

Nonetheless, the impact of major particle components other than the organic matter (e.g., mineral dust and sea salt) were more apparent in terms of the different ice nucleation activity observed under simulated mixed-phase cloud conditions. Therefore, we suggest that observed ice nucleation activity above $-30^{\circ} \mathrm{C}$ cannot be linked directly to the oxidative state of the organic matter on the surface of the particles. Instead, ice nucleation activity may be controlled more strongly by the major components governing their particle types. Furthermore, the IN active and non-active fractions showed different frequencies in terms of particles contain- ing oxidized and less oxidized organic matter. Also, IN active particles were more often associated with BBC peaks, which are suggestive of the presence of complex organic matter. The possibility remains, therefore, that less oxidized organic matter and BBC may partly be responsible for, or even enhance, the ice nucleation activity of the host particles.

\subsection{Sampling conditions: influence of aged Asian dust particles}

The study area, the city of Kanazawa, is located along the west coast of mainland Japan. Further upstream of the westerly continental outflow are the vast arid regions of inland China and Mongolia. Every spring, frequent dust outbreaks are observed, transporting a massive amount of mineral dust aerosols (Asian dust) across the region and beyond (Iwasaka et al., 2009a).

Backward trajectories suggested that the air mass at $3000 \mathrm{~m}$ altitude over the sampling location during the two sampling dates in February and April 2016 had traveled over Chinese and Mongolian regions (Fig. 11; redrawn from http://ready.arl.noaa.gov/HYSPLIT.php; Stein et al., 2015; Rolph, 2017). The range of coarse particle $(D>$ $1.0 \mu \mathrm{m})$ and number concentrations monitored by an optical particle counter (OPC KC-01E, RION, Japan) at the NOTO Ground-based Research Observatory (NOTOGRO; $37.45^{\circ} \mathrm{N}, 137.36^{\circ} \mathrm{E} ; 116 \mathrm{~km}$ northeast of the sampling location) (Iwamoto et al., 2016) during the sampling periods were significantly higher than the background concentrations $\left(0.31 \pm 0.12\right.$ particles $\left.\mathrm{cm}^{-3}\right)$ during the 2016 spring season. The average concentration observed during Asian dust events in February 2016 was $3.27 \pm 1.80$ particles $\mathrm{cm}^{-3}$, so the concentrations observed during the February sampling period were not as high as those expected during major Asian dust events. The April sampling date is reported as an Asian dust event day by the Japanese Meteorological Agency (http://www.data.jma.go.jp/gmd/env/kosahp/ kosa_table_2016.html). Indeed, the coarse particle concentration in April $\left(2.45 \pm 0.09\right.$ particles $\left.\mathrm{cm}^{-3}\right)$ was 3 times as high as that in the February $\left(0.85 \pm 0.08\right.$ particles $\left.\mathrm{cm}^{-3}\right)$ sampling period at the sampling location, and 5 times higher $\left(2.38 \pm 0.07\right.$ particles $\left.\mathrm{cm}^{-3}\right)$ than that in February $(0.49 \pm$ 0.04 particles $\mathrm{cm}^{-3}$ ) at NOTOGRO.

As discussed above, the mineral dust particles were the dominant group of IN active particles. The higher ice nucleation active fraction observed for the April sample $(5.6 \times$ $\left.10^{-3}\right)$ compared to the February sample $\left(3.6 \times 10^{-3}\right)$ can be related to the stronger influence of Asian dust particles.

Based on the result of individual particle analysis, the dust particles collected at the sampling location were internally mixed with sulfates, nitrates, sea salt, and organics. On the other hand, the ADS particles did not show signs of mixing with sulfates or nitrates, although they did contain either organic matter or BBC. This finding is in agreement with previous reports on Asian dusts collected at the 
(a) 28 February 2016

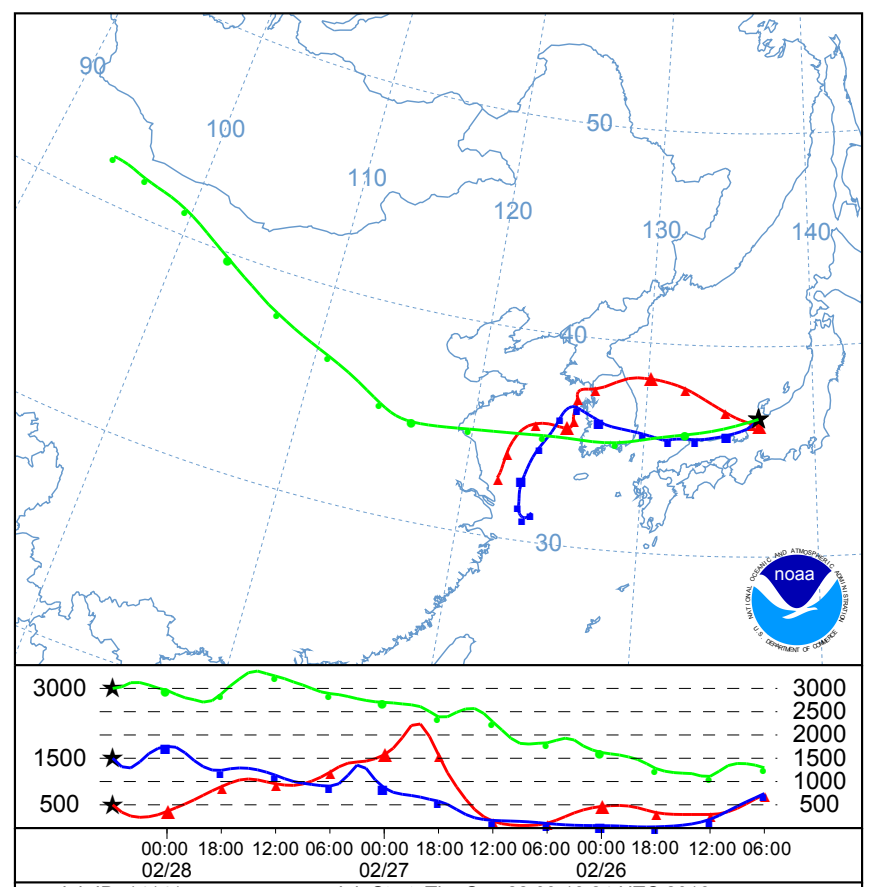

(b) 10 April 2016

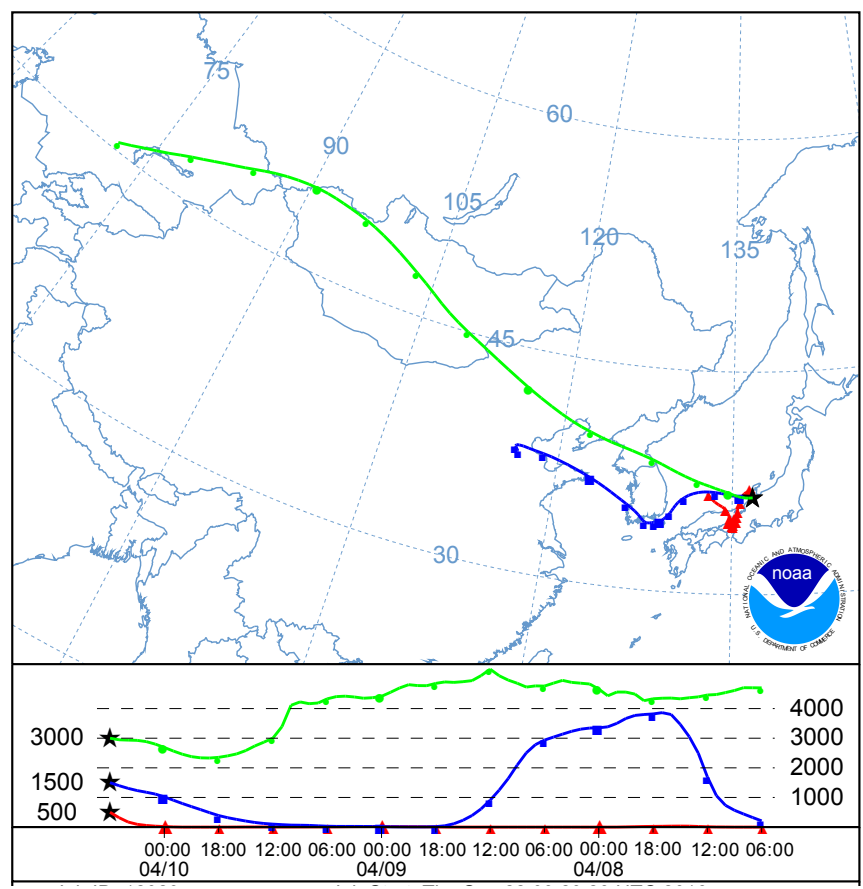

Figure 11. Backward trajectories of air masses that arrived at 3000, 1500, and $500 \mathrm{~m}$ over the sampling location during the sampling periods on 28 February and 10 April 2016.

desert surface, which are reported to contain organics originating from biomass burning and unsaturated fatty acid derived from plants (Kawamura and Gagosian, 1987; Kawamura et al., 2004). Therefore, our ice nucleation experiment is representative of the Asian dust plume, originally emitted from Chinese and Mongolian deserts, experiencing aging during long-range transport across the urban areas of China and/or the Sea of Japan, where particles became internally mixed with sulfates, nitrates, or sea salt (Zhang et al., 2003).

\section{Conclusions}

Ice nucleation experiments on both standard mineral samples and ambient aerosol particles were performed on an individual particle basis by the individual droplet freezing method, simulating conditions relevant for mixed-phase cloud formation. In addition, the morphology and chemical composition of both IN active and non-active particles were directly measured by three individual particle analysis methods.

Standard feldspar and quartz particles were shown to be more ice nucleation active than atmospheric particles. Among the ambient aerosol particles, aluminosilicate mineral dust and internally mixed Ca-rich and sulfate particles were identified as IN active particle types. Other IN active particles were identified as internal mixtures including sulfates, nitrates, and organics but commonly contained min- eral dust as a major component. These mineral dust particles were suggested to be mixtures of several clay mineral components rather than single mineral species, having defects in their crystal structure and containing impurities.

Dust particles consisting of pure mineral components, associated with high ice nucleation activity (e.g., K-feldspar) in previous laboratory experiments, were extremely rare or non-existent in the atmosphere, even under the influence of Asian dust transport. Therefore, the majority of immersionand condensation-mode IN particles in the atmosphere were identified as clay mineral particles on an individual particle basis. Our result suggests that the freezing temperatures of individual ice nuclei in the atmosphere do not show large variation and fall in a relatively narrow range that can be represented by the ice nucleation activity of clay minerals. This claim is consistent with those inferred from bulk analysis (Kaufmann et al., 2016).

Moreover, aged sea salt, pure calcite, mixtures of Ca-rich spherical particles with nitrates, and pure sulfate particles were found to be less active as ice nuclei. In particular, internal mixing with sea salt particles during transport over the ocean was shown to be an important factor inhibiting the ice nucleation activity of mixed counterparts. Cloud processing has been proposed as an efficient mechanism for mixing mineral dust and sea salt particles (Niimura et al., 1998), and such depression in the ice nucleation activity has 
important implications for subsequent condensation and immersion freezing pathways. Although relatively pure calcite and sulfate particles such as $\left(\mathrm{NH}_{4}\right)_{2} \mathrm{SO}_{4}$ were identified as an inert particle group, interestingly, these particles may nucleate ice following mixing by themselves (i.e., sulfate plus Ca-rich) or with other components (except for the mixing of calcite with nitrate). This also suggests that atmospheric aging (including cloud processing) could potentially enhance the originally inert ice nucleation activity of calcite and sulfate particles. These results suggest that the influences of dust aging and associated mixing during transport on ice nucleation activity are very complex, because in certain cases, the aging process may act to both promote and inhibit ice nucleation in mixed-phase clouds. Therefore, in addition to the original composition and related ice nucleation activities, the aging process in the atmosphere must also be considered when precisely predicting the ice nucleation activity of ambient aerosols.

The mineral dust particles were found to contain organic matter already at the emission source. Mixing with organics was found to have only a secondary effect on the ice nucleation activity of the host particles. The possibility remains, however, that the oxidation state of the organics and the presence of BBC on the particle surface may be partly involved in ice nucleation. Therefore, there is a further need to characterize the surface and coating state of atmospheric particles to better understand the specific factors responsible for ice nucleation in mixed-phase clouds. This is because ice nucleation is probably most sensitive to the particle surface or the first few layers below the surface, as ice germs are believed to grow from cracks, crevices, or pores.

In conclusion, this study successfully related immersionand condensation-mode ice nucleation activity of actual atmospheric particles to their morphology, chemical composition, and mixing states on an individual particle basis. This was made possible by the direct and comprehensive particle analysis of individual IN particles. We believe that this method can be used to verify previously proposed aerosol ice nucleation theories that are mostly based on experiments using single components and/or bulk samples.

Data availability. The back-trajectory data was calculated from the NOAA HYSPLIT model (http://ready.arl.noaa.gov/HYSPLIT. php). The other experimental data is provided upon request (matsuki@staff.kanazawa-u.ac.jp).

Supplement. The supplement related to this article is available online at: https://doi.org/10.5194/acp-18-1785-2018-supplement.

Competing interests. The authors declare that they have no conflict of interest.
Special issue statement. This article is part of the special issue "Anthropogenic dust and its climate impact". It does not belong to a conference.

Acknowledgements. We thank Shoji Arai, Tomoyuki Mizukami (Kanazawa University), and Norikatsu Akizawa (Kyoto University) for providing experimental equipment. We gratefully acknowledge the Fourth Laboratory, Forecast Research Department, Meteorological Research Institute for providing the ATD and valuable comments. The authors also acknowledge the NOAA Air Resources Laboratory (ARL) for provision of the HYSPLIT transport and dispersion model and/or the READY website (http://www.ready.noaa.gov) used in our work. This study was supported by the Japan Society for Promotion of Science (JSPS) Funding Program for Next Generation World-Leading Researchers (no. GR045).

Edited by: Kenji Kai

Reviewed by: three anonymous referees

\section{References}

Abbatt, J. P. D., Benz, S., Cziczo, D. J., Kanji, Z., Lohmann, U., and Möhler, O.: Solid ammonium sulfate aerosols as ice nuclei: a pathway for cirrus cloud formation, Science, 313, 1770-1773, https://doi.org/10.1126/science.1129726, 2006.

Adachi, K., Chung, S. H., Friedrich, H., and Buseck, P. R.: Fractal parameters of individual soot particles determined using electron tomography: Implications for optical properties, J. Geophys. Res.-Atmos., 112, D14202, https://doi.org/10.1029/2006JD008296, 2007.

Akizawa, N., Tamaru, A., Fukushi, K., Yamamoto, J., Mizukami, T., Python, M., and Arai, S.: High-temperature hydrothermal activities around suboceanic Moho: An example from diopsidite and anorthosite in Wadi Fizh, Oman ophiolite, Lithos, 263, 66-87, 2016.

Ardon-Dryer, K. and Levin, Z.: Ground-based measurements of immersion freezing in the eastern Mediterranean, Atmos. Chem. Phys., 14, 5217-5231, https://doi.org/10.5194/acp-145217-2014, 2014.

Atkinson, J. D., Murray, B. J., Woodhouse, M. T., Whale, T. F., Baustian, K. J., Carslaw, K. S., Dobbie, S., O'Sullivan, D., and Malkin, T. L.: The importance of feldspar for ice nucleation by mineral dust in mixed-phase clouds, Nature, 498, 355-358, https://doi.org/10.1038/nature12278, 2013.

Augustin-Bauditz, S., Wex, H., Denjean, C., Hartmann, S., Schneider, J., Schmidt, S., Ebert, M., and Stratmann, F.: Laboratorygenerated mixtures of mineral dust particles with biological substances: characterization of the particle mixing state and immersion freezing behavior, Atmos. Chem. Phys., 16, 5531-5543, https://doi.org/10.5194/acp-16-5531-2016, 2016.

Ault, A. P., Zhao, D., Ebben, C. J., Tauber, M. J., Geiger, F. M., Prather, K. A., and Grassian, V. H.: Raman microspectroscopy and vibrational sum frequency generation spectroscopy as probes of the bulk and surface compositions of size-resolved sea spray aerosol particles, Phys. Chem. Chem. Phys., 15, 6206-6212, https://doi.org/10.1039/C3CP43899F, 2013. 
Batonneau, Y., Sobanska, S., Laureyns, J., and Bremard, C.: Confocal microprobe Raman imaging of urban tropospheric aerosol particles, Environ. Sci. Technol., 40, 1300-1306, https://doi.org/10.1021/es051294x, 2006.

Baustian, K. J., Wise, M. E., and Tolbert, M. A.: Depositional ice nucleation on solid ammonium sulfate and glutaric acid particles, Atmos. Chem. Phys., 10, 2307-2317, https://doi.org/10.5194/acp-10-2307-2010, 2010.

Baustian, K. J., Cziczo, D. J., Wise, M. E., Pratt, K. A., Kulkarni, C., Hallar, A. G., and Tolbert, M. A.: Importance of aerosol composition, mixing state, and morphology for heterogeneous ice nucleation: a combined field and laboratory approach, J. Geophys. Res.-Atmos., 117, D06217, https://doi.org/10.1029/2011JD016784, 2012.

Boose, Y., Welti, A., Atkinson, J., Ramelli, F., Danielczok, A., Bingemer, H. G., Plötze, M., Sierau, B., Kanji, Z. A., and Lohmann, U.: Heterogeneous ice nucleation on dust particles sourced from nine deserts worldwide - Part 1: Immersion freezing, Atmos. Chem. Phys., 16, 15075-15095, https://doi.org/10.5194/acp-16-15075-2016, 2016.

Brooks, S. D., Suter, K., and Olivarez, L.: Effects of chemical aging on the ice nucleation activity of soot and polycyclic aromatic hydrocarbon aerosols, J. Phys. Chem. A, 118, 10036-10047, https://doi.org/10.1021/jp508809y, 2014.

Cantrell, W. and Heymsfield, A.: Production of ice in tropospheric clouds: a review, B. Am. Meteorol. Soc., 86, 795-807, https://doi.org/10.1175/BAMS-86-6-795, 2005.

Conen, F., Morris, C. E., Leifeld, J., Yakutin, M. V., and Alewell, C.: Biological residues define the ice nucleation properties of soil dust, Atmos. Chem. Phys., 11, 9643-9648, https://doi.org/10.5194/acp-11-9643-2011, 2011.

Connolly, P. J., Möhler, O., Field, P. R., Saathoff, H., Burgess, R., Choularton, T., and Gallagher, M.: Studies of heterogeneous freezing by three different desert dust samples, Atmos. Chem. Phys., 9, 2805-2824, https://doi.org/10.5194/acp-9-2805-2009, 2009.

Cziczo, D. J., DeMott, P. J., Brock, C., Hudson, P. K., Jesse, B., Kreidenweis, S. M., Prenni, A. J., Schreiner, J., Thomson, D. S., and Murphy, D. M.: A method for single particle mass spectrometry of ice nuclei, Aerosol Sci. Tech., 37, 460-470, https://doi.org/10.1080/02786820300976, 2003.

Cziczo, D. J., Stetzer, O., Worringen, A., Ebert, M., Weinbruch, S., Kamphus, M., Gallavardin, S. J., Curtius, J., Borrmann, S., Froyd, K. D., Mertes, S., Möhler, O., and Lohmann, U.: Inadvertent climate modification due to anthropogenic lead, Nat. Geosci., 2, 333-336, https://doi.org/10.1038/ngeo499, 2009.

Cziczo, D. J., Froyd, K. D., Hoose, C., Jensen, E. J., Diao, M., Zondlo, M. A., Smith, J. B., Twohy, C. H., and Murphy, D. M.: Clarifying the dominant sources and mechanisms of cirrus cloud formation, Science, 340, 1320-1324, https://doi.org/10.1126/science.1234145, 2013.

DeMott, P. J.: An exploratory study of ice nucleation by soot aerosols, J. Appl. Meteorol., 29, 1072-1079, https://doi.org/10.1175/15200450(1990)029<1072:AESOIN>2.0.CO;2, 1990.

DeMott, P. J., Chen, Y., Kreidenweis, S. M., Rogers, D. C., and Sherman, D. E.: Ice formation by black carbon particles, Geophys. Res. Lett., 26, 2429-2432, https://doi.org/10.1029/1999GL900580, 1999.
Diehl, K. and Mitra, S. K.: A laboratory study of the effects of a kerosene-burner exhaust on ice nucleation and the evaporation rate of ice crystals, Atmos. Environ., 32, 3145-3151, https://doi.org/10.1016/S1352-2310(97)00467-6, 1998.

Ebert, M., Worringen, A., Benker, N., Mertes, S., Weingartner, E., and Weinbruch, S.: Chemical composition and mixing-state of ice residuals sampled within mixed phase clouds, Atmos. Chem. Phys., 11, 2805-2816, https://doi.org/10.5194/acp-112805-2011, 2011.

Escribano, R., Sloan, J. J., Siddique, N., Sze, N., and Dudev, T.: Raman spectroscopy of carbon-containing particles, Vib. Spectrosc., 26, 179-186, https://doi.org/10.1016/S09242031(01)00106-0, 2001.

Flato, G., Marotzke, J., Abiodun, B., Braconnot, P., Chou, S. C., Collins, W., Cox, P., Driouech, F., Emori, S., Eyring, V., Forest, C., Gleckler, P., Guilyardi, E., Jakob, C., Kattsov, V., Reason, C., and Rummukainen, M.: Evaluation of climate models, in: Climate Change 2013: The Physical Science Basis. Contribution of Working Group I to the Fifth Assessment Report of the Intergovernmental Panel on Climate Change, Stocker, T. F., Qin, D., Plattner, G.-K., Tignor, M., Allen, S. K., Boschung, J., Nauels, A., Xia, Y., Bex, V., and Midgley, P. M., Cambridge University Press, Cambridge, UK and New York, NY, USA, 741866, 2013.

Fornea, A. P., Brooks, S. D., Dooley, J. B., and Saha, A.: Heterogeneous freezing of ice on atmospheric aerosols containing ash, soot, and soil, J. Geophys. Res., 114, D13201, https://doi.org/10.1029/2009JD011958, 2009.

Gaft, M., Reisfeld, R., and Panczer, G.: Modern Luminescence Spectroscopy of Minerals and Materials, Springer-Verlag, Berlin, Heidelberg, https://doi.org/10.1007/b137490, 2005.

Hara, K., Maki, T., Kakikawa, M., Kobayashi, F., and Matsuki, A.: Effects of different temperature treatments on biological ice nuclei in snow samples, Atmos. Environ., 140, 415-419, https://doi.org/10.1016/j.atmosenv.2016.06.011, 2016.

Harrison, A. D., Whale, T. F., Carpenter, M. A., Holden, M. A., Neve, L., O'Sullivan, D., Temprado, J. V., and Murray, B. J.: Not all feldspars are equal: a survey of ice nucleating properties across the feldspar group of minerals, Atmos. Chem. Phys., 16, 10927-10940, https://doi.org/10.5194/acp-16-109272016, 2016.

Hiranuma, N., Brooks, S. D., Gramann, J., and Auvermann, B. W.: High concentrations of coarse particles emitted from a cattle feeding operation, Atmos. Chem. Phys., 11, 8809-8823, https://doi.org/10.5194/acp-11-8809-2011, 2011.

Hoose, C. and Möhler, O.: Heterogeneous ice nucleation on atmospheric aerosols: a review of results from laboratory experiments, Atmos. Chem. Phys., 12, 9817-9854, https://doi.org/10.5194/acp-12-9817-2012, 2012.

Huffman, J. A., Sinha, B., Garland, R. M., Snee-Pollmann, A., Gunthe, S. S., Artaxo, P., Martin, S. T., Andreae, M. O., and Pöschl, U.: Size distributions and temporal variations of biological aerosol particles in the Amazon rainforest characterized by microscopy and real-time UV-APS fluorescence techniques during AMAZE-08, Atmos. Chem. Phys., 12, 11997-12019, https://doi.org/10.5194/acp-12-11997-2012, 2012.

Ivleva, N. P., Messerer, A., Yang, X., Niessner, R., and Pöschl, U.: Raman microspectroscopic analysis of changes in the chemical structure and reactivity of soot in a diesel exhaust aftertreat- 
ment model system, Environ. Sci. Technol., 41, 3702-3707, https://doi.org/10.1021/es0612448, 2007.

Iwamoto, Y., Kinouchi, K., Watanabe, K., Yamazaki, N., and Matsuki, A.: Simultaneous measurement of CCN activity and chemical composition of fine mode aerosols at Noto Peninsula, Japan, in autumn 2012, Aerosol Air Qual. Res., 16, 2107-2118, https://doi.org/10.4209/aaqr.2015.09.0545, 2016.

Iwasaka, Y., Nishikawa, M., Yamada, M., and Hong, C. S.: KOSA, Kokin Shoin Press, Tokyo, 342 p., 2009a (in Japanese).

Iwasaka, Y., Shi, G. Y., Yamada, M., Kobayashi, F., Kakikawa, M., Maki, T., Chen, B., Tobo, Y., and Hong, C.: Mixture of Kosa (Asian dust) and bioaerosols detected in the atmosphere over the Kosa particles source regions with balloon-borne measurements: possibility of long-range transport, Air Qual. Atmos. Hlth., 2, 29-38, 2009b.

Jung, H. J., Eom, H. J., Kang, H. W., Moreau, M., Sobanska, S., and Ro, C. U.: Combined use of quantitative ED-EPMA, Raman microspecrometry, and ATR-FTIR imaging techniques for the analysis of individual particles, Analyst, 139, 3949-3960, https://doi.org/10.1039/c4an00380b, 2014.

Kamphus, M., Ettner-Mahl, M., Klimach, T., Drewnick, F., Keller, L., Cziczo, D. J., Mertes, S., Borrmann, S., and Curtius, J.: Chemical composition of ambient aerosol, ice residues and cloud droplet residues in mixed-phase clouds: single particle analysis during the Cloud and Aerosol Characterization Experiment (CLACE 6), Atmos. Chem. Phys., 10, 8077-8095, https://doi.org/10.5194/acp-10-8077-2010, 2010.

Kaufmann, L., Marcolli, C., Hofer, J., Pinti, V., Hoyle, C. R., and Peter, T.: Ice nucleation efficiency of natural dust samples in the immersion mode, Atmos. Chem. Phys., 16, 11177-11206, https://doi.org/10.5194/acp-16-11177-2016, 2016.

Kawamura, K. and Gagosian, R. B.: Implications of $\omega$ oxocarboxylic acids in the remote marine atmosphere for photooxidation of unsaturated fatty acids, Nature, 325, 330-332, https://doi.org/10.1038/325330a0, 1987.

Kawamura, K., Kobayashi, M., Tsubonuma, N., Mochida, M., Watanabe, T., and Lee, M.: Organic and inorganic compositions of marine aerosols from East Asia: Seasonal variations of watersoluble dicarboxylic acids, major ions, total carbon and nitrogen, and stable $\mathrm{C}$ and $\mathrm{N}$ isotopic composition, in: Geochemical Investigation in Earth and Space Science: A Tribute to Isaac R. Kaplan, edited by: Hill, R. J., Leventhal, J., Aizenshtat, Z., Baedecker, M. J., Claypool, G., Eganhouse, R., Goldhaber, M., and Peters, K., The Geochemical Society Special Publications Elsevier, vol. 9, 243-265, 2004.

Kireeva, E. D., Popovicheva, O. B., Persiantseva, N. M., Khokhlova, T. D., and Shonija, N. K.: Effect of black carbon particles on the efficiency of water droplet freezing, Colloid J.+, 71, 353-359, https://doi.org/10.1134/S1061933X09030090, 2009.

Klein, H., Haunold, W., Bundke, U., Nillius, B., Wetter, T., Schallenberg, S., and Bingemer, H.: A new method for sampling of atmospheric ice nuclei with subsequent analysis in a static diffusion chamber, Atmos. Res., 96, 218-224, https://doi.org/10.1016/j.atmosres.2009.08.002, 2010.

Knopf, D. A., Wang, B., Laskin, A., Moffet, R. C., and Gilles, M. K.: Heterogeneous nucleation of ice on anthropogenic organic particles collected in Mexico City, Geophys. Res. Lett., 37, L11803, https://doi.org/10.1029/2010GL043362, 2010.
Knopf, D. A., Alpert, P. A., Wang, B., O’Brien, R. E., Kelly, S. T., Laskin, A., Gilles, M. K., and Moffet, R. C.: Microspectroscopic imaging and characterization of individually identified ice nucleating particles from a case field study, J. Geophys. Res.-Atmos., 119, JD021866, https://doi.org/10.1002/2014JD021866, 2014.

Koop, T., Luo, B. P., Tsias, A., and Peter, T.: Water activity as the determinant for homogeneous ice nucleation in aqueous solutions, Nature, 406, 611-614, 2000.

Korolev, A.: Limitations of the Wegener-Bergeron-Findeisen Mechanism in the Evolution of Mixed-Phase Clouds, J. Atmos. Sci., 64, 3372-3375, https://doi.org/10.1175/JAS4035.1, 2007.

Kulkarni, G., Sanders, C., Zhang, K., Liu, X., and Zhao, C.: Ice nucleation of bare and sulfuric acid-coated mineral dust particles and implication for cloud properties, J. Geophys. Res.-Atmos., 119, 9993-10011, https://doi.org/10.1002/2014JD021567, 2014.

Kupiszewski, P., Weingartner, E., Vochezer, P., Schnaiter, M., Bigi, A., Gysel, M., Rosati, B., Toprak, E., Mertes, S., and Baltensperger, U.: The Ice Selective Inlet: a novel technique for exclusive extraction of pristine ice crystals in mixed-phase clouds, Atmos. Meas. Tech., 8, 3087-3106, https://doi.org/10.5194/amt8-3087-2015, 2015.

Laskin, A., Iedema, M. J., Ichkovich, A., Graber, E. R., Taraniuk, I., and Rudich, Y.: Direct observation of completely processed calcium carbonate dust particles, Faraday Discuss., 130, 453-468, https://doi.org/10.1039/b417366j, 2005.

Laskina, O., Young, M. A., Kleiber, P. D., and Grassian, V. H.: Infrared extinction spectroscopy and micro-Raman spectroscopy of select components of mineral dust mixed with organic compounds, J. Geophys. Res.-Atmos., 118, 6593-6606, https://doi.org/10.1002/jgrd.50494, 2013.

Lohmann, U. and Feichter, J.: Global indirect aerosol effects: a review, Atmos. Chem. Phys., 5, 715-737, https://doi.org/10.5194/acp-5-715-2005, 2005.

Maki, T., Susuki, S., Kobayashi, F., Kakikawa, M., Tobo, Y., Yamada, M., Higashi, T., Matsuki, A., Hong, C., Hasegawa, H., and Iwasaka, Y.: Phylogenetic analysis of atmospheric halotolerant bacterial communities at high altitude in an Asian dust (KOSA) arrival region, Suzu City, Sci. Total Environ., 408, 4556-4562, https://doi.org/10.1016/j.scitotenv.2010.04.002, 2010.

Maring, H., Savoie, D. L., Izaguirre, M. A., Custals, L., and Reid, J. S.: Mineral dust aerosol size distribution change during atmospheric transport, J. Geophys. Res.-Atmos., 108, 8592, https://doi.org/10.1029/2002JD002536, 2003.

Mason, R. H., Chou, C., McCluskey, C. S., Levin, E. J. T., Schiller, C. L., Hill, T. C. J., Huffman, J. A., DeMott, P. J., and Bertram, A. K.: The micro-orifice uniform deposit impactordroplet freezing technique (MOUDI-DFT) for measuring concentrations of ice nucleating particles as a function of size: improvements and initial validation, Atmos. Meas. Tech., 8, 24492462, https://doi.org/10.5194/amt-8-2449-2015, 2015.

Matsuki, A., Iwasaka, Y., Osada, K., Matsunaga, K., Kido, M., Inomata, Y., Trochkine, D., Nishita, C., Nezuka, T., Sakai, T., Zhang, D., and Kwon, S.-A.: Seasonal dependence of the longrange transport and vertical distribution of free tropospheric aerosols over east Asia: On the basis of aircraft and lidar measurements and isentropic trajectory analysis, J. Geophys. Res.-Atmos., 108, 8663, https://doi.org/10.1029/2002JD003266, 2003. 
Matsuki, A., Iwasaka, Y., Shi, G. Y., Zhang, D. Z., Trochkine, D., Yamada, M., Kim, Y. S., Chen, B., Nagatani, T., Miyazawa, T., Nagatani, M., and Nakata, H.: Morphological and chemical modification of mineral dust: Observational insight into the heterogeneous uptake of acidic gases, Geophys. Res. Lett., 32, L22806, https://doi.org/10.1029/2005GL024176, 2005.

Mertes, S., Verheggen, B., Walter, S., Connolly, P., Ebert, M., Schneider, J., Bower, K. N., Cozic, J., Weinbruch, S., Baltensperger, U., and Weingartner, E.: Counterflow virtual impactor based collection of small ice particles in mixed-phase clouds for the physico-chemical characterization of tropospheric ice nuclei: sampler description and first case study, Aerosol Sci. Tech., 41, 848-864, https://doi.org/10.1080/02786820701501881, 2007.

Morris, C. E., Georgakopoulos, D. G., Sands, D. C.: Ice nucleation active bacteria and their potential role in precipitation, J. Phys. IV, 121, 87-103, https://doi.org/10.1051/jp4:2004121004, 2004.

Murray, B. J., Broadley, S. L., Wilson, T. W., Bull, S. J., Wills, R. H., Christenson, H. K., and Murrary, E. J.: Kinetics of the homogeneous freezing of water, Phys. Chem. Chem. Phys., 12, 10380 10387, https://doi.org/10.1039/C003297B, 2010.

Murray, B. J., Broadley, S. L., Wilson, T. W., Atkinson, J. D., and Wills, R. H.: Heterogeneous freezing of water droplets containing kaolinite particles, Atmos. Chem. Phys., 11, 4191-4207, https://doi.org/10.5194/acp-11-4191-2011, 2011.

Murray, B. J., O'Sullivan, D., Atkinson, J. D., and Webb, M. E.: Ice nucleation by particles immersed in supercooled cloud droplets, Chem. Soc. Rev., 41, 6519-6554, https://doi.org/10.1039/C2CS35200A, 2012.

Möhler, O., Benz, S., Saathoff, H., Schnaiter, M., Wagner, R., Schneider, J., Walter, S., Ebert, V., and Wagner, S.: The effect of organic coating on the heterogeneous ice nucleation efficiency of mineral dust aerosols, Environ. Res. Lett., 3, 025007, https://doi.org/10.1088/1748-9326/3/2/025007, 2008a.

Möhler, O., Georgakopoulos, D. G., Morris, C. E., Benz, S., Ebert, V., Hunsmann, S., Saathoff, H., Schnaiter, M., and Wagner, R.: Heterogeneous ice nucleation activity of bacteria: new laboratory experiments at simulated cloud conditions, Biogeosciences, 5, 1425-1435, https://doi.org/10.5194/bg-5-1425-2008, 2008b.

Niemand, M., Möhler, O., Vogel, B., Vogel, H., Hoose, C., Connolly, P., Klein, H., Bingemer, H., DeMott, P., Skrotzki, J., and Leisner, T.: A particle-surface-area-based parameterization of immersion freezing on desert dust particles, J. Atmos. Sci., 69, 3077-3092, https://doi.org/10.1175/Jas-D-11-0249.1, 2012.

Niimura, N., Okada, K., Fan, X. B., Kai, K., Arao, K., Shi, G. Y., and Takahashi, S.: Formation of Asian dust-storm particles mixed internally with sea-salt in the atmosphere, J. Meteorol. Soc. Jpn., 76, 275-288, 1998.

O'Sullivan, D., Murray, B. J., Malkin, T. L., Whale, T. F., Umo, N. S., Atkinson, J. D., Price, H. C., Baustian, K. J., Browse, J., and Webb, M. E.: Ice nucleation by fertile soil dusts: relative importance of mineral and biogenic components, Atmos. Chem. Phys., 14, 1853-1867, https://doi.org/10.5194/acp-141853-2014, 2014.

Petters, M. D., Parsons, M. T., Prenni, A. J., DeMott, P. J., Kreidenweis, S. M., Carrico, C. M., Sullivan, A. P., McMeeking, G. R., Levin, E., Wold, C. E., Collett Jr., J. L., and Moosmüller, H.: Ice nuclei emissions from biomass burning, J. Geophys. Res., 114, D07209, https://doi.org/10.1029/2008JD011532, 2009.
Prenni, A. J., Demott, P. J., Rogers, D. C., Kreidenweis, S. M., McFarquhar, G. M., Zhang, G., and Poellot, M. R.: Ice nuclei characteristics from M-PACE and their relation to ice formation in clouds, Tellus B, 61, 436-448, https://doi.org/10.1111/j.16000889.2009.00415.x, 2009a.

Prenni, A. J., Petters, M. D., Faulhaber, A., Carrico, C. M., Ziemann, P. J., Kreidenweis, S. M., and DeMott, P. J.: Heterogeneous ice nucleation measurements of secondary organic aerosol generated from ozonolysis of alkenes, Geophys. Res. Lett., 36, L06808, https://doi.org/10.1029/2008GL036957, 2009b.

Prenni, A. J., DeMott, P. J., Sullivan, A. P., Sullivan, R. C., Kreidenweis, S. M., and Rogers, D. C.: Biomass burning as a potential source for atmospheric ice nuclei: Western wildfires and prescribed burns, Geophys. Res. Lett., 39, L11805, https://doi.org/10.1029/2012GL051915, 2012.

Pruppacher, H. R. and Klett, J. D.: Microphysics of Clouds and Precipitation, Kluwer Academic Publishers, Dordrecht, the Netherlands, 1997.

Pummer, B. G., Bauer, H., Bernardi, J., Bleicher, S., and Grothe, H.: Suspendable macromolecules are responsible for ice nucleation activity of birch and conifer pollen, Atmos. Chem. Phys., 12, 2541-2550, https://doi.org/10.5194/acp-12-2541-2012, 2012.

Rogers, D. C., DeMott, P. J., Kreidenweis, S. M., and Chen, Y.: Measurements of ice nucleating aerosols during SUCCESS, Geophys. Res. Lett., 25, 1383-1386, https://doi.org/10.1029/97GL03478, 1998.

Rolph, G. D.: Real-time Environmental Applications and Display sYstem (READY), National Oceanic and Atmospheric Administration (NOAA), Air Resources Laboratory (ARL), College Park, MD, USA, 2017.

Rosenfeld, D. and Woodley, W. L.: Deep convective clouds with sustained supercooled liquid water down to $-37.5^{\circ} \mathrm{C}$, Nature, 405, 440-442, https://doi.org/10.1038/35013030, 2000.

Rosenfeld, D., Lohmann, U., Raga, G. B., O’Dowd, C. D., Kulmala, M., Fuzzi, S., Reissel, A., and Andreae, M. O.: Flood or drought: How do aerosols affect precipitation?, Science, 321, 1309-1313, https://doi.org/10.1126/science.1160606, 2008.

Sadezky, A., Muckenhuber, H., Groyhe, H., Niessner, R., and Pöschl: Raman microspectroscopy of soot and related carbonaceous materials: spectral analysis and structural information, Carbon, 43, 1731-1742, https://doi.org/10.1016/j.carbon.2005.02.018, 2005.

Schrod, J., Danielczok, A., Weber, D., Ebert, M., Thomson, E. S., and Bingemer, H. G.: Re-evaluating the Frankfurt isothermal static diffusion chamber for ice nucleation, Atmos. Meas. Tech., 9, 1313-1324, https://doi.org/10.5194/amt-9-1313-2016, 2016.

Schrod, J., Weber, D., Drücke, J., Keleshis, C., Pikridas, M., Ebert, M., Cvetković, B., Nickovic, S., Marinou, E., Baars, H., Ansmann, A., Vrekoussis, M., Mihalopoulos, N., Sciare, J., Curtius, J., and Bingemer, H. G.: Ice nucleating particles over the Eastern Mediterranean measured by unmanned aircraft systems, Atmos. Chem. Phys., 17, 4817-4835, https://doi.org/10.5194/acp17-4817-2017, 2017.

Sobanska, S., Hwang, H., Choel, M., Jung, H.-J., Eom, H.-J., Kim, H., Barbillat, J., and Ro, C.-U.: Investigation of the chemical mixing state of individual Asian dust particles by the combined use of electron probe X-ray microanalysis and Raman microspectrometry, Anal. Chem., 84, 3145-3154, 2012. 
Sobanska, S., Falgayrac, G., Rimetz-Planchon, J., Perdrix, E., Brémard, C., and Barbillat, J.: Resolving the internal structure of individual atmospheric aerosol particle by the combination of Atomic Force Microscopy, ESEM-EDX, Raman and ToF-SIMS imaging, Microchem. J., 114, 89-98, https://doi.org/10.1016/j.microc.2013.12.007, 2014.

Stein, A. F., Draxler, R.R, Rolph, G. D., Stunder, B. J. B., Cohen, M. D., and Ngan, F.: NOAA's HYSPLIT atmospheric transport and dispersion modeling system, B. Am. Meteorol. Soc., 96, 2059-2077, https://doi.org/10.1175/BAMS-D-14$00110.1,2015$.

Sullivan, R. C., Guazzotti, S. A., Sodeman, D. A., and Prather, K. A.: Direct observations of the atmospheric processing of Asian mineral dust, Atmos. Chem. Phys., 7, 1213-1236, https://doi.org/10.5194/acp-7-1213-2007, 2007.

Sullivan, R. C., Petters, M. D., DeMott, P. J., Kreidenweis, S. M., Wex, H., Niedermeier, D., Hartmann, S., Clauss, T., Stratmann, F., Reitz, P., Schneider, J., and Sierau, B.: Irreversible loss of ice nucleation active sites in mineral dust particles caused by sulphuric acid condensation, Atmos. Chem. Phys., 10, 1147111487, https://doi.org/10.5194/acp-10-11471-2010, 2010.

Tang, I. N. and Fung, K. H.: Characterization of inorganic salt particles by Raman spectroscopy, J. Aerosol Sci., 20, 609-617, https://doi.org/10.1016/0021-8502(89)90106-7, 1989.

Tobo, Y., Zhang, D., Matsuki, A., and Iwasaka, Y.: Asian dust particles converted into aqueous droplets under remote marine atmospheric conditions, P. Natl. Acad. Sci. USA, 107, 17905-17910, https://doi.org/10.1073/pnas.1008235107, 2010.

Tobo, Y., DeMott, P. J., Hill, T. C. J., Prenni, A. J., SwobodaColberg, N. G., Franc, G. D., and Kreidenweis, S. M.: Organic matter matters for ice nuclei of agricultural soil origin, Atmos. Chem. Phys., 14, 8521-8531, https://doi.org/10.5194/acp14-8521-2014, 2014.

Tong, H.-J., Reid, J. P., Bones, D. L., Luo, B. P., and Krieger, U. K.: Measurements of the timescales for the mass transfer of water in glassy aerosol at low relative humidity and ambient temperature, Atmos. Chem. Phys., 11, 4739-4754, https://doi.org/10.5194/acp-11-4739-2011, 2011.

Trochkine, D., Iwasaka, Y., Matsuki, A., Yamada, M., Kim, Y.S., Nagatani, T., Zhang, D., Shi, G.-Y., and Shen Z.: Mineral aerosol particles collected in Dunhuang, China, and their comparison with chemically modified particles collected over Japan, J. Geophys. Res.-Atmos., 108, 8642, https://doi.org/10.1029/2002JD003268, 2003.

Twohy, C. H., McMeeking, G. R., DeMott, P. J., McCluskey, C. S., Hill, T. C. J., Burrows, S. M., Kulkarni, G. R., Tanarhte, M., Kafle, D. N., and Toohey, D. W.: Abundance of fluorescent biological aerosol particles at temperatures conducive to the formation of mixed-phase and cirrus clouds, Atmos. Chem. Phys., 16, 8205-8225, https://doi.org/10.5194/acp-16-8205-2016, 2016.

Ueda, S., Osada, K., and Takami, A.: Morphological features of soot-containing particles internally mixed with watersoluble materials in continental outflow observed at Cape Hedo, Okinawa, Japan, J. Geophys. Res.-Atmos., 116, D17207, https://doi.org/10.1029/2010JD015565, 2011.
Whale, T. F., Murray, B. J., O’Sullivan, D., Wilson, T. W., Umo, N. S., Baustian, K. J., Atkinson, J. D., Workneh, D. A., and Morris, G. J.: A technique for quantifying heterogeneous ice nucleation in microlitre supercooled water droplets, Atmos. Meas. Tech., 8, 2437-2447, https://doi.org/10.5194/amt-8-2437-2015, 2015.

Wilson, T. W., Ladino, L. A., Alpert, P. A., Breckels, M. N., Brooks, I. M., Browse, J., Burrows, S. M., Carslaw, K. S., Huffman, J. A., Judd, C., Kilthau, W. P., Mason, R. H., McFiggans, G., Miller, L. A., Nájera, J. J., Polishchuk, E., Rae, S., Schiller, C. L., Si, M., Temprado, J. V., Whale, T. F., Wong, J. P. S., Wurl, O., Yakobi-Hancock, J. D., Abbatt, J. P. D., Aller, J. Y., Bertram, A. K., Knopf, D. A., and Murray, B. J.: A marine biogenic source of atmospheric ice-nucleating particles, Nature, 525, 234-238, https://doi.org/10.1038/nature14986, 2015.

Wise, M. E., Baustian, K. J., Koop, T., Freedman, M. A., Jensen, E. J., and Tolbert, M. A.: Depositional ice nucleation onto crystalline hydrated $\mathrm{NaCl}$ particles: a new mechanism for ice formation in the troposphere, Atmos. Chem. Phys., 12, 1121-1134, https://doi.org/10.5194/acp-12-1121-2012, 2012.

Worringen, A., Kandler, K., Benker, N., Dirsch, T., Mertes, S., Schenk, L., Kästner, U., Frank, F., Nillius, B., Bundke, U., Rose, D., Curtius, J., Kupiszewski, P., Weingartner, E., Vochezer, P., Schneider, J., Schmidt, S., Weinbruch, S., and Ebert, M.: Single-particle characterization of ice-nucleating particles and ice particle residuals sampled by three different techniques, Atmos. Chem. Phys., 15, 4161-4178, https://doi.org/10.5194/acp15-4161-2015, 2015.

Yabuki, S., Kanayama, S., and Honda, M.: Mineral composition of certified reference material: China loess $(\mathrm{CJ} 1)$ and simulated asian mineral dust (CJ2), Chikyu Kankyo, 7, 171-179, 2002 (in Japanese).

Zhang, D., Iwasaka, Y., Shi, G., Zang, J., Matsuki, A., and Trochkine, D.: Mixture state and size of Asian dust particles collected at southwestern Japan in spring 2000, J. Geophys. Res.-Atmos., 108, 4760, https://doi.org/10.1029/2003JD003869, 2003.

Zimmermann, F., Weinbruch, S., Schütz, L., Hofmann, H., Ebert, M., Kandler, K., and Worringen, A.: Ice nucleation properties of the most abundant mineral dust phases, J. Geophys. Res.Atmos., 113, D23204, https://doi.org/10.1029/2008JD010655, 2008.

Zolles, T., Burkart, J., Häusler, T., Pummer, B., Hitzenberger, R., and Grothe, H.: Identification of ice nucleation active sites on feldspar dust particles, J. Phys. Chem. A, 119, 2692-2700, https://doi.org/10.1021/jp509839x, 2015. 